\title{
Mapping of Modifiable Factors with Interdisciplinary Chronic Obstructive Pulmonary Disease (COPD) Guidelines Adherence to the Theoretical Domains Framework: A Systematic Review
}

\author{
Hancy Issac $\mathbb{D}^{1,2}$ \\ Clint Moloney ${ }^{1,3,4}$ \\ Melissa Taylor (D) ${ }^{1,2}$ \\ Jackie Lea ${ }^{1,2}$
}

'School of Nursing and Midwifery, University of Southern Queensland, Toowoomba, Australia; ${ }^{2}$ Centre for Health Research, University of Southern Queensland, Toowoomba, Australia; ${ }^{3}$ College of Health and Biomedicine, Nursing and Midwifery, Victoria University, Melbourne, Australia; ${ }^{4}$ Clinical Community Health and Wellbeing, Research Institute for Health and Sport, Victoria University, Melbourne, Australia

Correspondence: Hancy Issac

W562, School of Nursing and Midwifery, University of Southern Queensland,

Toowoomba, Queensland, Australia

Tel +6I 746312269

Email hancy.issac@usq.edu.au

\begin{abstract}
Background: COPD guidelines non-concordance is a challenge frequently highlighted by respiratory experts. Despite the provision of comprehensive evidence-based national and international guidelines, the COPD burden to frontline healthcare services has increased in the last decade. Suboptimal guidelines concordance can be disruptive to health-related quality of life (HRQoL), hastening pulmonary function decline and surging overall morbidity and mortality. A lack of concordance with guidelines has created an escalating economic burden on health-care systems. Identifying interdisciplinary interventions to facilitate improved adherence to guidelines may significantly reduce re-admissions, enhance HRQoL amongst patients and their families, and facilitate economic efficiency.
\end{abstract}

Materials and Methods: This review adhered to the Joanna Briggs Institute (JBI) methodology for mixed methods systematic reviews and the PRISMA ScR reporting guidelines. Two independent reviewers screened abstracts and full text articles in consonance with inclusion criteria. The convergent integrative JBI method collated quantitative, qualitative and mixed methods studies from nine databases. JBI critical appraisal tools were utilised to assess the quality of research papers. The theoretical domains framework (TDF) along with a specifically developed COPD data extraction tool were adopted as a priori to collect and collate data. Identified barriers and corresponding clinical behavioural change solutions were categorised using TDF domains and behavior change wheel $(\mathrm{BCW})$ to provide future research and implementation recommendations.

Results: Searches returned 1068 studies from which 37 studies were included (see Figure 1). COPD recommendations identified to be discordant with clinical practice included initiating non-invasive ventilation, over- or under-prescription of corticosteroids and antibiotics, and a lack of discharging patients with a smoking cessation plan or pulmonary rehabilitation. TDF domains with highest frequency scores were knowledge, environmental resources, and clinical behaviour regulation. Electronic order sets/digital proforma with guideline resources at point of care and easily accessible digital community referrals to target both pharmacological and non-pharmacological management appear to be a solution to improve concordance.

Conclusion: Implementation of consistent quality improvement intervention within hospitals for patients with COPD may exclude any implementation gap and prevent readmissions. Electronic proformas with digital referrals will assist with future evaluation audits to prioritise and target interventions to improve guidelines concordance.

Ethics and Dissemination: Ethical approval is not required, and results dissemination will occur through peer-reviewed publication.

PROSPERO Registration Number: CRD42020156267. 
Keywords: COPD guidelines, chronic obstructive pulmonary disease guidelines, concordance, compliance, adherence, GOLD, COPD-X

\section{Introduction}

Chronic obstructive pulmonary disease (COPD) is a progressive life-threatening lung disease identified as a major global healthcare burden. ${ }^{1}$ According to the World Health Organization, COPD caused 3.23 million deaths in 2019 equating to $6 \%$ of overall deaths, with over $80 \%$ of those occurring in low- and middle-income countries. ${ }^{2}$ The Australian National Morbidity Database reveals that in 2017-2018, there were 77,660 hospitalisations of people over 45, with the rate of hospitalisation at 732 per 100,000 population. $^{3}$ In Australia, $7.5 \%$ of people $\geq 40$ years old have stage II or above COPD as classified by the Global
Initiative for Obstructive Lung Disease (GOLD) criteria and $30 \%$ in the $>75$-years age group. ${ }^{3,4}$ COPD is the fifth leading cause of death in Australia and second avoidable cause of hospitalisation. ${ }^{3,4}$ Worldwide, COPD related mortality ranks high amongst developed countries with the United States at 8th, United Kingdom at 12th and Australia at 34th. ${ }^{5}$ Patients with COPD and their families experience a considerable financial burden due to functional decline in the workplace and at home. COPD prevalence, morbidity, and mortality is highly reported from high-income countries albeit $90 \%$ mortality occurs in low and middle-income countries. ${ }^{6}$ In an Australian context in

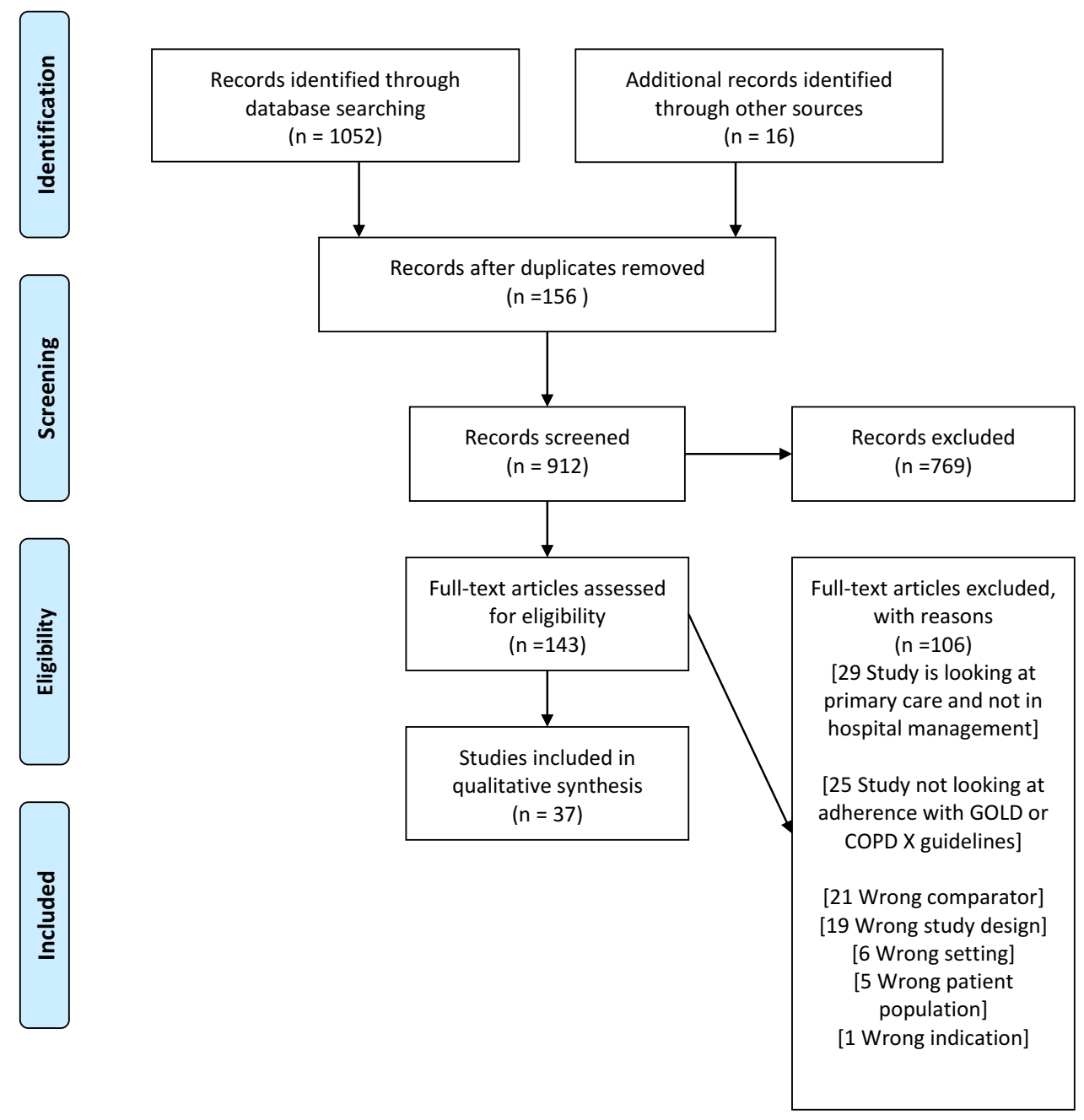

Figure I Preferred reporting items for systematic reviews and meta-analyses: the PRISMA statement.

Notes: PRISMA figure adapted from Moher D, Liberati A, Altman D, Tetzlaff J et al. The PRISMA statement for reporting systematic reviews and meta-analyses of studies that evaluate health care interventions: explanation and elaboration. Journal of clinical epidemiology. 2009;62(10). Creative Commons. ${ }^{68}$ 
2015-2016, the treatment of patients with COPD was estimated to reach $\$ 976.9$ million, which was $24 \%$ of total expenditure for all respiratory conditions. ${ }^{6}$ Globally, COPD is predicted to increase its economic burden by US $\$ 2.3$ trillion by $2030 .{ }^{1}$ Varied COPD treatment and effective long-term preventative management strategies are however known to decrease the number of acute exacerbations, improve health-related quality of life outcomes, and sustain pulmonary function. ${ }^{7}$

National guidelines in Australia (COPD-X plan) and international guidelines (Global Initiative for Chronic Obstructive Lung Disease [GOLD]) continue to highlight the significance of non-pharmacological interventions to improve HrQoL, prevent readmissions and acute exacerbations. ${ }^{8,9}$ COPD guidelines non-adherence in both pharmacological and non-pharmacological management is well-recognised and is a reported phenomenon in national and international literature. ${ }^{10-12}$ A COCHRANE systematic review on integrated disease management programs for COPD reported improved disease-related quality of life, increased exercise capacity, reduced hospital admissions and hospital days per person. ${ }^{13}$ Sub-optimal dissemination and implementation impede adoption into clinical practice by interdisciplinary health professionals. ${ }^{14,15}$ Guidelines assist with the incorporation of evidence into clinical practice to improve patient outcomes. ${ }^{16,17}$ However, worldwide research reports lack of COPD guideline adherence. ${ }^{11,18-22}$ Implications of guidelines non concordanceare repetitive readmissions with COPD exacerbations, increased economic burden, and poor optimisation of lung function and overall health. ${ }^{12,23,24}$

This systematic review set out to identify known contributing factors towards COPD guidelines nonadherence from the time of admission to hospital to time of discharge. Given the scarcity of research on interdisciplinary guidelines concordance with the population of patients with COPD, the review included a mixed methods approach that enabled all available evidence to be incorporated into the review. The Theoretical Domains Framework (TDF) assists in helping to identify factors that influence a behavior. The TDF framework is used by researchers to identify factors; interventions were filtered and targeted towards interdisciplinary implementation with specific recommendations for local, national, and international health systems. ${ }^{25-27}$ The Theoretical Domains Framework collation of data allowed robust filtration of evidence from multiple sources to provide improved implementation strategies and clinical behaviour change solutions utilising behavior change wheel taxonomy to augment COPD guidelines concordance. ${ }^{25,27}$ Identified barriers, facilitators and corresponding clinical behavioral change solutions utilising a behavior change wheel are categorised towards 14 TDF domains. ${ }^{25,26}$ These include knowledge, skills, social/professional role identity, beliefs about capabilities, beliefs about consequences, memory attention and decision processes, environmental context and resources, intentions, goals, social influences, optimism, emotion, behavior regulation. Table 1 includes TDF domains and frequency scores with barriers and potential solutions from included studies (see Table 1). We hypothesised notable discordance in adherence to COPD guidelines and asserted that compiling modifiable factors and implementation strategies may improve awareness, increase adherence, and assist stakeholders to adopt implementation strategies to improve patient outcomes.

\section{Methods}

This review adheres to the Joanna Briggs Institute Methodology for Mixed Methods Systematic Reviews and the Preferred Reporting Items for Systematic Reviews and Meta-Analyses extension for Scoping Reviews Reporting Guidelines. The protocol for this study was published and registered in PROSPERO which elaborates on objective, search strategy, eligibility criteria, study selection, data collection, transformation and synthesis. ${ }^{14}$ The mixed methods review provides a comprehensive synthesis compared with a single-method review as it combines quantitative and qualitative evidence to assist clinical decision-makers and policymakers to adopt an appropriate implementation strategy. ${ }^{28}$ A convergent integrative method where quantitative evidence was qualitised to provide a narrative review is included to enable the integration of all studies and the ability to attain a deepened understanding of any discrepancies noted in the evidence (see Figure 2). ${ }^{28}$ The $14 \mathrm{TDF}$ domains and BCW taxonomy have guided the process for developing interventions specifically targeting identified barriers in three behavior change conditions: capability, opportunity, and motivation (referred to as the COM-B system). ${ }^{25}$ Identified TDF domains causing non-adherence to guidelines were mapped to the capability (C), opportunity $(\mathrm{O})$, and motivation $(\mathrm{M})$ components, which form the behavior change wheel with nine intervention functions (education, persuasion, incentivisation, coercion, 
Table I TDF ${ }^{\mathrm{a}}$ Domains and Frequency Scores with Barriers and Potential Solutions from Included Studies

\begin{tabular}{|c|c|c|c|c|c|c|}
\hline Discordant Clinical Practice & TDF $^{\mathrm{a}}$ Domain & COPD $^{a}$ Guidelines Uptake Barrier & $\begin{array}{l}\text { COM-Ba } \\
\text { Components }\end{array}$ & BCW $/$ /Study Recommendations & $\begin{array}{l}\text { Solutions/Future Research } \\
\text { Recommendations }\end{array}$ & $\begin{array}{l}\text { Frequency } \\
\text { Scores } / 37\end{array}$ \\
\hline 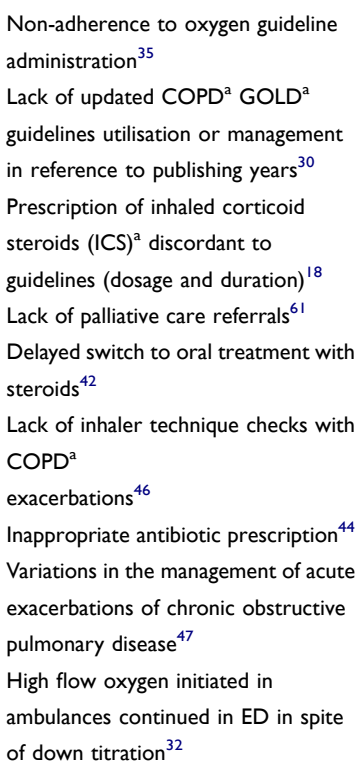 & Knowledge & $\begin{array}{l}\text { Lack of understanding of the effects, role } \\
\text { and dangers of oxygen therapy } \\
\text { Lack of familiarity of COPD }^{35} \\
\text { guidelines }^{23,53} \\
\text { Lack of knowledge on updated guideline } \\
\text { with publishing years } \\
\text { Difficulty prognosticating in palliative care } \\
\text { COPD due to the variable disease }^{30} \\
\text { trajectory } \\
\text { Lack of awareness of the consequences of }^{61} \\
\text { poorly controlled disease } \\
\text { Care gaps between general internists, } \\
\text { respiratory physicians and hospitals } \\
\text { Lack of knowledge of spirometry } \\
\text { interpretation }\end{array}$ & $\begin{array}{l}\text { Capability } \\
\text { (psychological, } \\
\text { Physical) }\end{array}$ & $\begin{array}{l}\text { Training, modeling, enablement } \\
\text { Education and other interventions to enhance self-learning } \\
\text { among physicians } \\
\text { Introduction of hospital guidelines }^{21} \\
\text { Implementation and education of updated guideline versions in } \\
\text { clinical practice } \\
\text { Educate clinicians of the indications and contraindications for } \\
\text { ICS }^{30} \text { and encourage to prescribe according to the guidelines } \\
\text { Education of professionals involved in the care of COPD } \\
\text { patients may reduce the risk of complications of hypercapnia } \\
52\end{array}$ & $\begin{array}{l}\text { Electronic care order set and } \\
\text { prescribing at point of } \\
\text { care }^{10-12,18,20,47,52} \\
\text { Informational posters } \\
\text { Training all nurses, pharmacists } \\
\text { and allied health to share } \\
\text { responsibility in inhaler device } \\
\text { and technique education }{ }^{49,58} \\
\text { Clinical bundles/pathways to } \\
\text { standardise care particularly } \\
\text { with pharmacological } \\
\text { management } \\
\text { Targe,20,29,33,34,65 } \\
\text { education for each discipline }{ }^{58} \\
\text { Interactive educational tools, } \\
\text { specific cue cards in clinical } \\
\text { practice and presence of } \\
\text { hospital clinical champions }\end{array}$ & $28 / 37$ \\
\hline $\begin{array}{l}\text { Lack of inhaler technique checks with } \\
\text { COPD }^{a} \text { exacerbation } \\
\text { I9 } \\
\text { Inhaler device specific guidance } \\
\text { appears to be lacking }{ }^{34} \\
\text { Lacking skills to teach device specific } \\
\text { inhaler technique }{ }^{28} \\
\text { Lack of previous experience with }^{\text {NIV initiation }}{ }^{11,52}\end{array}$ & Skills & $\begin{array}{l}\text { Lack of clear and specific guidance } \\
\text { regarding inhalation devices in current } \\
\text { COPD }^{\text {a guidelines }} \\
\text { Lack of staff education on NIV', }{ }^{29}\end{array}$ & $\begin{array}{l}\text { Capability } \\
\text { (physical) }\end{array}$ & $\begin{array}{l}\text { Training, Modeling } \\
\text { The development and validation of appropriate educational tools } \\
\text { for inhaler technique is necessary to assist clinicians and other } \\
\text { health-care professionals who are involved in selecting inhalation } \\
\text { devices }{ }^{33,49}\end{array}$ & $\begin{array}{l}\text { Inhaler technique educational } \\
\text { videos for patient education in } \\
\text { clinical practice }^{15} \\
\text { Self-learning E-modules for staff } \\
\text { in all departments }{ }^{15} \\
\text { Training all nurses, pharmacists } \\
\text { and allied health to share } \\
\text { responsibility in inhaler device } \\
\text { and technique education } \\
\text { Increasing education and }^{\text {Increas }} \\
\text { disseminating guidelines in the } \\
\text { working area utilising better } \\
\text { implementation and change } \\
\text { management strategies }{ }^{12}\end{array}$ & $10 / 37$ \\
\hline
\end{tabular}




\begin{tabular}{|c|c|c|c|c|c|c|}
\hline $\begin{array}{l}\text { Respiratory specialists and nurses } \\
\text { adhered national guidelines more } \\
\text { accurately over internists } \\
\text { Misalignment of prescribing with } \\
\text { GOLDD }^{\mathrm{S}} \text { recommendations between } \\
\text { respiratory physician and general } \\
\text { physician } \\
\text { Lack of clinician and multidisciplinary } \\
\text { team co-operation } 18,38 \\
\text { The role of carers was poorly } \\
\text { recognised in end stage COPD } \\
\text { Palliative care or advance care planning } \\
\text { not offered to end stage COPD } \\
\text { patients }\end{array}$ & $\begin{array}{l}\text { Social/ } \\
\text { Professional } \\
\text { role and } \\
\text { identity }\end{array}$ & $\begin{array}{l}\text { Lack of inter speciality communication } \\
\text { and guidance amongst clinicians } \\
\text { Communic.5 } \\
\text { Committeation between Guideline } \\
\text { improved } \\
\text { Variabiliticians should be } \\
\text { of hospources and organizats, pation } \\
\text { process of care, and ourcteomes }{ }^{59}\end{array}$ & $\begin{array}{l}\text { Opportunity } \\
\text { (Social) }\end{array}$ & $\begin{array}{l}\text { Persuasion, Enablement; Cross fertilization of knowledge } \\
\text { and practice patterns across clinicians so that all patients could } \\
\text { receive evidence-based care in the most efficient manner } \\
\text { (respiratory specialist clinicians versus internists) }\end{array}$ & $\begin{array}{l}\text { Admission and Discharge } \\
\text { bundle of care to integrate } \\
\text { primary and tertiary care } \\
\text { Nurse facilitated reminder } \\
\text { system }^{35}\end{array}$ & $9 / 37$ \\
\hline $\begin{array}{l}\text { Care gaps in the inpatient } \\
\text { management of AECOPD } \\
\text { guidelines } 11,12,36 \\
\text { The prevalence of clinical depression } \\
\text { in patients with COPD } \\
18 \% \text { to varies from } 80 \% \text {, yet not screened } \\
\text { regularly with AECOPD, }{ }^{59} \\
\text { Screening and pharmacological } \\
\text { treatment for clinically confirmed } \\
\text { depression not done as part of } \\
\text { routine care }{ }^{59}\end{array}$ & $\begin{array}{l}\text { Environmental } \\
\text { context and } \\
\text { resources } \\
\text { (staffing, } \\
\text { funding, other } \\
\text { resources) }\end{array}$ & 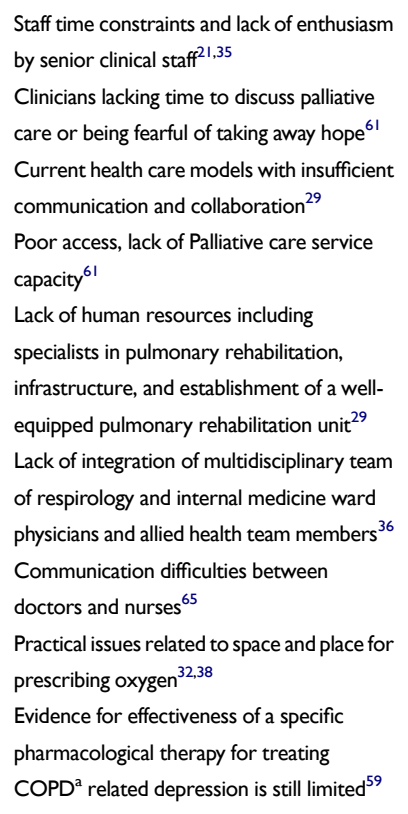 & $\begin{array}{l}\text { Opportunity } \\
\text { (physical) }\end{array}$ & $\begin{array}{l}\text { Environmental restructuring, persuasion, } \\
\text { Incentivisation } \\
\text { Patient centred and coordinated interdisciplinary care across } \\
\text { Primary, acute and community sector }{ }^{38} \\
\text { Integrated, multidisciplinary services, are urgently required to } \\
\text { address the unmet needs of people and carers with advanced } \\
\text { COPD }^{31} \\
\text { COPD }^{\mathrm{a}} \text { quality initiative framework for systematic follow-up of } \\
\text { guideline to avoid variance of practices.65 } \\
\text { Care pathway implementation improves adherence with } \\
\text { guidelines } \\
\text { Pharmacological and non-pharmacological treatment options } \\
\text { with cognitive behavioural based therapies, education, patient } \\
\text { centred programmes }\end{array}$ & $\begin{array}{l}\text { Automatic electronic linkage } \\
\text { between hospital and } \\
\text { community }^{\prime 5} \\
\text { Simple preformatted order sets } \\
\text { may be readily integrated into } \\
\text { the diverse electronic health } \\
\text { record plafforms that currently } \\
\text { exist across different } \\
\text { hospitals }^{10,12,4,54} \\
\text { Message alerts on computer } \\
\text { login screens } \\
{ }^{1,12,20,24}\end{array}$ & $16 / 37$ \\
\hline $\begin{array}{l}\text { Oxygen prescribing practices non } \\
\text { adherent to guidelines }^{32} \\
\text { Difficulty remembering updated } \\
\text { guidelines }^{30}\end{array}$ & $\begin{array}{l}\text { Memory } \\
\text { attention }\end{array}$ & $\begin{array}{l}\text { Difficulty recalling all delivery devices and } \\
\text { management modality from COPD } \\
\text { guidelines }{ }^{1,12,41}\end{array}$ & $\begin{array}{l}\text { Capability } \\
\text { (psychological) }\end{array}$ & $\begin{array}{l}\text { Environmental restructuring, Enablement, Education } \\
\text { Point of care checklist in respiratory wards have improved } \\
\text { guideline adherence }^{12} \\
\text { Health professional education and self-learning resources }^{38} \\
\text { Decision-making algorithms (including electronic systems) and } \\
\text { reminders at the time of consultation, and continuous quality } \\
\text { assurance programmes }\end{array}$ & $\begin{array}{l}\text { Admission bundle with } \\
\text { electronic prescribing system }{ }^{20} \\
\text { Easy access to guidelines in } \\
\text { clinical areas }^{12} \\
\text { Electronic order sets } \\
33,7,54,12,18,20,\end{array}$ & $8 / 37$ \\
\hline
\end{tabular}


Table I (Continued).

\begin{tabular}{|c|c|c|c|c|c|c|}
\hline Discordant Clinical Practice & TDF $^{\mathrm{a}}$ Domain & COPD $^{\mathrm{a}}$ Guidelines Uptake Barrier & $\begin{array}{l}\text { COM-Ba } \\
\text { Components }\end{array}$ & BCW'/Study Recommendations & $\begin{array}{l}\text { Solutions/Future Research } \\
\text { Recommendations }\end{array}$ & $\begin{array}{l}\text { Frequency } \\
\text { Scores } / 37\end{array}$ \\
\hline 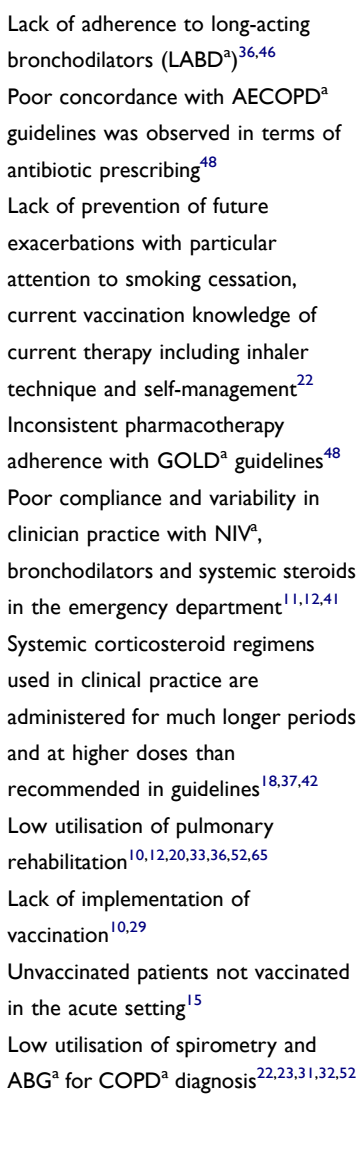 & $\begin{array}{l}\text { Behavioural } \\
\text { regulation }\end{array}$ & $\begin{array}{l}\text { Failure to adhere to GOLD } \text { guidelines } \\
\text { LABD }^{\mathrm{a}} \text { prescription } \\
\text { Suboptimal understanding of guideline } \\
\text { recommendations lack of perceived } \\
\text { treatment benefit, low self-efficacy and } \\
\text { time constraints } \\
\text { Poor uptake of evidence by clinicians } \\
\text { Varying standards of } \text { PR }^{\mathrm{a}} \text { program and } \\
\text { access }^{23,36}\end{array}$ & $\begin{array}{l}\text { Capability } \\
\text { (Psychological) }\end{array}$ & 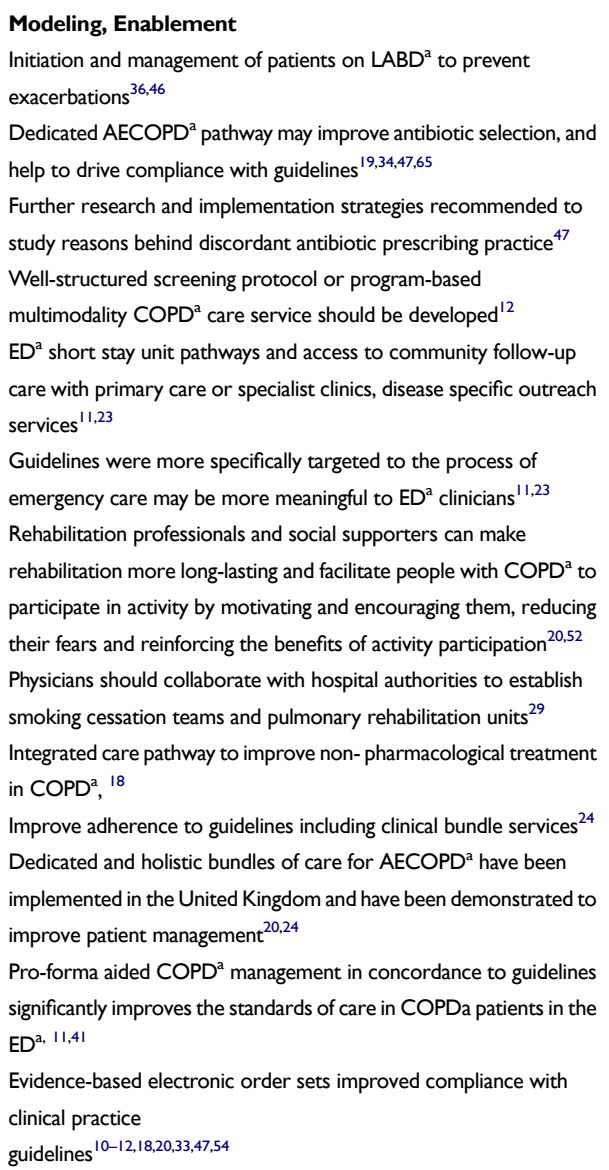 & $\begin{array}{l}\text { Electronic order sets }{ }^{10-12,18,20,} \\
33,47,54 \\
\text { Evaluation audits and targeted } \\
\text { health professional education } \\
\text { for each discipline }{ }^{58}\end{array}$ & 36 \\
\hline
\end{tabular}

Abbreviations: ${ }^{a} T D F$, theoretical domains framework; BCW, behavior change wheel; COM-B, capability, opportunity, motivation; COPD, chronic obstructive pulmonary disease; GOLD, Global Initiative Obstructive Lung Disease; AECOPD, acute exacerbation of COPD; NIV, non-invasive ventilation; ABG, arterial blood gas; LABD, long-acting bronchodilators; ICS, inhaled corticosteroids; PR, pulmonary rehabilitation; ED, emergency department. 


\section{JBI convergent integrated mixed method review}

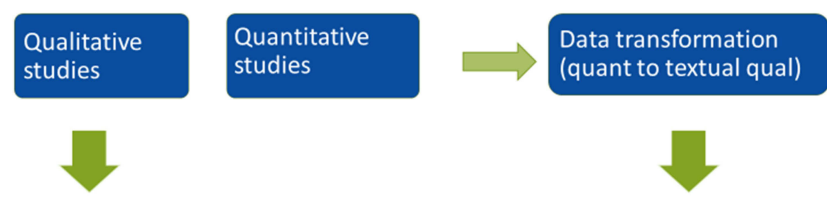

Qualitative synthesis of Qualitative + Quantitative data

Figure 2 Represents data extraction graphic representation.

Note: Research design stages from JBI convergent integrated method for systematic review [Data extracted from Stern et al., 2020] ${ }^{28}$.

training, restriction, environmental restructuring, modeling and enablement) and seven policy change categories (guidelines, environmental/social planning, communication/marketing, legislation, service provision, regulation, fiscal measures). ${ }^{25}$ Sub-components of COM-B were merged with the domains, barriers, and recommendations from the studies to produce interventions that if adopted by clinical stakeholders may assist in enhancing COPD guideline adherence.

\section{Review Questions}

What core elements of the COPD guidelines are adhered to by interdisciplinary health professionals?

What are the contributing factors to the lack of COPD guidelines concordance amongst interdisciplinary health professionals in hospitals?

\section{Search Strategy and Study Selection}

Qualitative, quantitative, and mixed methods studies were included to explore determinants of COPD guidelines concordance. A comprehensive three-tier search strategy was utilised to search nine databases (COCHRANE, EBSCO HOST, MEDLINE, SCIENCE DIRECT, JBI, SCOPUS, WEB OF SCIENCE, WILEY and DARE). ${ }^{14}$ Studies published in English from 2010 to May 2021 from the nine identified databases were included. Although the protocol mentions including studies from 1997, during the review reported factors of non-adherence data was non-congruent with study reports in recent years. Hence, studies published before 2010 were excluded. Two independent reviewers screened abstracts (HI, CM) and full-text articles (HI, CM), (HI, MT), (HI, JL) in consonance with inclusion criteria. Disagreements that arose between the reviewers at each stage of the study selection process were resolved through discussion, or with a third reviewer (CM/MT). A PRISMA report of the search process and outcomes was produced.
Inclusion criteria consisted of studies and reports published on interdisciplinary COPD guidelines concordance, compliance, or adherence in the hospital setting. Reviews of GOLD guidelines and COPD X plan guidelines were included. Exclusion criteria included studies not reported in English and studies which had not measured COPD guideline concordance. Primary health-care and community-based COPD guidelines concordance studies were excluded. The study population involved doctors, nurses, and allied health-worker reports on COPD guidelines concordance in the context of data from emergency departments, inpatient hospital units and hospital-based rehabilitation units.

\section{Quality Appraisal}

Quality appraisal was performed by two independent reviewers (HI, CM) utilising specific standardised critical appraisal instruments from the JBI system. Studies that were selected regardless of the methodological quality underwent extraction and synthesis. Critical appraisal results were tabled and appended to the review retrieval. See Supplementary Material.1).

\section{Data Extraction and Transformation}

A mixed methods data extraction tool designed for a convergent integrated approach (integration of qualitative data and "qualitised" data following data transformation) was published in the protocol and utilised to extract data. ${ }^{14}$ This extraction tool included study type, the methodology, the number and characteristics of participants, the phenomenon of lack of concordance, guideline type, context (cultural and geographic), setting (hospitals, EDs and inpatient units), concordance with main recommendations of COPD guidelines, implementation method, evaluation and sustainability of implementation, and remissions within 30 days of hospital discharge. Two independent reviewers confirmed extracted data from articles and any 
disagreements were settled using the third reviewer utilising COVIDENCE systematic review management software. Quantitative data were converted to "qualitised data" following extraction according to the JBI convergent integrated approach. Quantitative numerical data were transfigured to textual or narrative interpretations to answer the overarching review question.

\section{Data Synthesis and Integration}

Extracted data in the form of themed textual description from quantitative studies plus themes and subthemes from qualitative studies were collated and categorised in congruence to 14 domains of TDF (see Table 1). Applying the TDF assisted in identification of determinants or factors leading to a lack of COPD guidelines concordance. Identified barriers and enablers in guideline uptake were aligned with standard taxonomy of behavioral change technique to report existing and future recommendations for implementation strategies. ${ }^{25,26}$ Factors contributing to the lack of concordance with the guidelines were integrated based on similarity in meaning. This review adhered to the PRISMA-ScR reporting guidelines which also provided a comprehensive approach to suggest implementation strategies regarding any identified publication bias of this guidelines non-concordance phenomenon.

\section{Results}

This review included 37 studies (see Figure 1), that reported on COPD-X or GOLD guidelines concordance with 14 studies reported from Australia, 12 from Europe, 2 from Canada and the remaining 9 from developing countries. Table 2 contains included studies demographics, barriers, potential solutions or recommendations (see Table 2). COPD recommendations identified as highly discordant from clinical practice were initiating non-invasive ventilation, over- or under-prescription of corticosteroids, antibiotic use, and lack of discharging patients with smoking cessation and pulmonary rehabilitation plans. TDF domains with highest frequency scores above 15 and over 37 were knowledge, environmental resources, and clinical behavior regulation. Domains that scored below 15 were skills, memory attention and decision processes, social/ professional role identity. Results are disseminated in the following paragraphs as problems, related TDF domains bracketed within results, supporting evidence or statistics, solutions, and recommended implementation strategies from the literature.

\section{Diagnostic Utilisation of Spirometry, ABG and Oxygen Management}

GOLD and COPD-X guidelines state diagnosis should occur utilising gold standard spirometry to detect persistent airflow limitation, however only $41 \%$ of Nigerian physicians knew spirometry diagnostic criteria and only $26.9 \%$ were aware of how to assess severity (knowledge). ${ }^{29}$ Low rate of guideline adherence with $61.5 \%$ for 2011 and $49.6 \%$ for 2017 GOLD guidelines were reported from a Korean study. ${ }^{30}$ Low utilisation of Arterial Blood Gas (ABG) data to utilise non-invasive ventilation (NIV) and diagnostic inaccuracy with respiratory failure is frequently reported in multiple studies. ${ }^{11,22-25}$ Despite suitable ABG and NIV equipment being available patients were not started on this treatment. ${ }^{22-24,30,31}$ Lack of knowledge and awareness of spirometry guidelines was identified as a key contributor to mistreatment, misdiagnosis, and inaccurate management. ${ }^{11,12,19,20,23,29,31,32}$ Unavailability of spirometry test results despite previous diagnosis and admissions (behavioral regulation) was consistently addressed as a barrier from fragmented discharge planning and primary care diagnostic intervention. ${ }^{22}$ Spirometry awareness campaigns and care bundles have successfully increased knowledge in some countries. ${ }^{18-20,24,33,34}$ An accurate assessment of smoking history as a surrogate measure of the severity of COPD was reported as a potential substitute to spirometry particularly in the ED during acute exacerbation episodes when pulmonary function tests cannot be performed due to severity of presentation. ${ }^{8,18,23}$

An Australian retrospective clinical audit reported unnecessary use of NIV in patients with adequate oxygenation (knowledge, behavior regulation) ${ }^{10,35}$ whereas another Australian study reported NIV was not utilised adequately despite meeting the guideline criteria (behavior regulation). ${ }^{36}$ Low adherence was reported from Europe, Australia and Ireland in pre-hospital oxygen management which continues in the emergency department (until specialist review) with poor clinical outcome such as hypercapnic respiratory failure (social/professional role and identity). ${ }^{10,22,24,36,37}$ Several patients not having an ABG test documented also received high-flow oxygen. ${ }^{23}$ Highflow oxygen was used for the initial treatment of COPD exacerbations when only $53 \%$ of patients were recognised to have COPD. ${ }^{32}$ In addition to patients not having an ABG test documented also receiving high-flow oxygen (behavior regulation), ${ }^{11,22,38}$ reduced awareness of guidelines especially among junior doctors was identified (knowledge). ${ }^{39}$ A reported disjunct exists between holistic 
Table 2 Included Studies Demographics, Barriers, Potential Solutions/Recommendations

\begin{tabular}{|c|c|c|c|c|c|c|c|}
\hline $\begin{array}{l}\text { Included } \\
\text { Studies } \\
\text { References }\end{array}$ & Title & Aims & Methods & Country & $\begin{array}{l}\text { Sample } \\
\text { Size }\end{array}$ & Barriers & $\begin{array}{l}\text { Solutions/Research } \\
\text { Recommendations }\end{array}$ \\
\hline $\begin{array}{l}\text { 1) Smallwood } \\
2018^{60}\end{array}$ & $\begin{array}{l}\text { Attitudes to specialist palliative } \\
\text { care and advance care planning } \\
\text { in people with COPD: a multi- } \\
\text { national survey of palliative and } \\
\text { respiratory medicine } \\
\text { specialists }\end{array}$ & $\begin{array}{l}\text { To explore the approaches of respiratory } \\
\text { and palliative medicine specialists to } \\
\text { palliative care and advance care planning } \\
\text { (ACP) in advanced COPD }\end{array}$ & Cohort study & $\begin{array}{l}\text { Australia, New } \\
\text { Zealand, and UK }\end{array}$ & $\begin{array}{l}\mathrm{N}=440 \\
\text { Respiratory- } \\
117 \\
\text { clinicians } \\
\text { Palliative- } \\
263 \\
\text { clinicians }\end{array}$ & $\begin{array}{l}\text { Difficulty in prognosis of COPD due to } \\
\text { the variable disease trajectory. Clinicians } \\
\text { lacking time to discuss palliative care or } \\
\text { being fearful of taking away hope palliative } \\
\text { specialist availability } \\
\text { Current health care models with } \\
\text { insufficient communication and } \\
\text { collaboration } \\
\text { Poor access, lack of palliative care service } \\
\text { capacity }\end{array}$ & $\begin{array}{l}\text { Patient led Advanced Care Planning } \\
\text { discussions } \\
\text { Respiratory doctors to initiate the } \\
\text { conversation and refer to palliative } \\
\text { specialist for individualised planning } \\
\text { Integrated multidisciplinary services to } \\
\text { address fragmented care }\end{array}$ \\
\hline $\begin{array}{l}\text { 2) Lipari } \\
2018^{18}\end{array}$ & $\begin{array}{l}\text { Adherence to GOLD } \\
\text { Guidelines in the Inpatient } \\
\text { COPD }^{\text {a Population }}\end{array}$ & $\begin{array}{l}\text { Assessed the management of inpatient } \\
\text { COPD }^{\mathrm{a}} \text { exacerbations at an urban } \\
\text { teaching hospital }\end{array}$ & $\begin{array}{l}\text { Cohort study } \\
\text { (Retrospective) }\end{array}$ & United States & $\begin{array}{l}N=94 \\
\text { patients }\end{array}$ & $\begin{array}{l}\text { Consistent variation in provider guideline } \\
\text { adherence. Variability in dosing schedule } \\
\text { and duration of corticosteroids } \\
\text { Vaccination document lower in summer } \\
\text { months (10\%) Approximately half of } \\
\text { COPD }{ }^{\mathrm{a}} \text { readmissions in this hospital did } \\
\text { not receive steroids during their first } \\
\text { admission }\end{array}$ & $\begin{array}{l}\text { Electronic care order sets for consistent } \\
\text { steroid prescription. Improve } \\
\text { documentation during hospital admission } \\
\text { utilising electronic medical record. } \\
\text { Quality improvement projects to improve } \\
\text { guideline adherence utilising clinical } \\
\text { bundle services }\end{array}$ \\
\hline $\begin{array}{l}\text { 3) Marcos } \\
\text { 2017 }\end{array}$ & $\begin{array}{l}\text { Treatment with Systemic } \\
\text { Steroids in Severe Chronic } \\
\text { Obstructive Pulmonary } \\
\text { Disease Exacerbations: Use of } \\
\text { Short Regimens in Routine } \\
\text { Clinical Practice and Their } \\
\text { Impact on Hospital Stay }\end{array}$ & $\begin{array}{l}\text { Explore short courses of systemic } \\
\text { corticosteroids are followed in clinical } \\
\text { practice }\end{array}$ & $\begin{array}{l}\text { Cohort study } \\
\text { (Prospective } \\
\text { observational) }\end{array}$ & Spain & $\begin{array}{l}N=158 \\
\text { patients }\end{array}$ & $\begin{array}{l}\text { Real world practices vary from guidelines } \\
\text { and impact hospital stay } \\
\text { Delayed switch to oral treatment } \\
\text { Doses of corticosteroid use in asthma } \\
\text { being transferred to COPD } \\
\text { Risk of adrenal crisis due to abrupt } \\
\text { withdrawal of prescribed dose } \\
\text { Despite the evidence oral steroids are } \\
\text { not inferior to intravenous steroids usage } \\
\text { of IV steroids } \\
\text { Recommended duration is tripled as to } 5 \\
\text { days in practice }\end{array}$ & $\begin{array}{l}\text { Factors such as social considerations, } \\
\text { hospital inefficiencies and continued care } \\
\text { after discharge needs to be further } \\
\text { researched }\end{array}$ \\
\hline $\begin{array}{l}\text { 4) } \\
\text { Masoompour } \\
2016^{58}\end{array}$ & 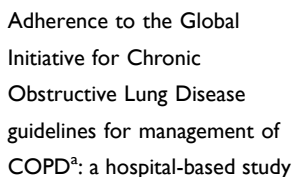 & $\begin{array}{l}\text { To determine the level of adherence to } \\
\text { the GOLD guidelines, we compared our } \\
\text { inpatient management o COPD to these } \\
\text { guidelines }\end{array}$ & $\begin{array}{l}\text { Cross sectional } \\
\text { study }\end{array}$ & Iran & $\begin{array}{l}\mathrm{N}=96 \\
\text { patients } \\
\text { admission }\end{array}$ & $\begin{array}{l}\text { No local standard guidelines for managing } \\
\text { COPD in Iran }\end{array}$ & $\begin{array}{l}\text { Develop targeted interventions aimed at } \\
\text { improving the implementation of } \\
\text { guidelines } \\
\text { Further research to determine the } \\
\text { efficacy of this new interventions }\end{array}$ \\
\hline
\end{tabular}

(Continued) 
Table 2 (Continued).

\begin{tabular}{|c|c|c|c|c|c|c|c|}
\hline $\begin{array}{l}\text { Included } \\
\text { Studies } \\
\text { References }\end{array}$ & Title & Aims & Methods & Country & $\begin{array}{l}\text { Sample } \\
\text { Size }\end{array}$ & Barriers & $\begin{array}{l}\text { Solutions/Research } \\
\text { Recommendations }\end{array}$ \\
\hline $\begin{array}{l}\text { 5) Melani } \\
2016^{49}\end{array}$ & $\begin{array}{l}\text { Maintaining Control of } \\
\text { Chronic Obstructive Airway } \\
\text { Disease: Adherence to Inhaled } \\
\text { Therapy and Risks and Benefits } \\
\text { of Switching Devices }\end{array}$ & $\begin{array}{l}\text { To evaluate the issues involved in } \\
\text { maintaining control of COPD, } \\
\text { predominantly related to adherence to } \\
\text { prescribed inhaled medications, and the } \\
\text { potential benefit and risks of switching } \\
\text { devices }\end{array}$ & Critical review & Italy & $\begin{array}{l}\text { Search } \\
\text { strategy not } \\
\text { mentioned }\end{array}$ & $\begin{array}{l}\text { Lack of awareness of the consequences of } \\
\text { poorly controlled disease } \\
\text { Concerns about drug side effects, or loss } \\
\text { of efficacy, or development of addiction } \\
\text { Poor medical-patient communication; } \\
\text { poor medical-other health caregivers' } \\
\text { partnership in patient's education. Lack of } \\
\text { continuity of care, no written plan; } \\
\text { physician's underestimation of disease } \\
\text { control; poor supervision, training, or } \\
\text { follow-up of patients; and poor education } \\
\text { to inhaler training }\end{array}$ & $\begin{array}{l}\text { Easier-to-use devices and educational } \\
\text { strategies on proper inhaler use from } \\
\text { health caregivers can improve inhaler } \\
\text { technique. } \\
\text { Switching to a more appropriate patient } \\
\text { centred inhaled therapy is recommended. } \\
\text { A comprehensive list including all inhalers } \\
\text { in the market, edited by scientific } \\
\text { societies face-to-face practical instruction } \\
\text { of proper inhaler use at prescription, and } \\
\text { regular checks at follow-up visits. } \\
\text { Training other staff other than physicians } \\
\text { to provide inhaler technique education }\end{array}$ \\
\hline $\begin{array}{l}\text { 6) Menzella } \\
2012^{19}\end{array}$ & $\begin{array}{l}\text { Clinical audit on diagnostic } \\
\text { accuracy and management of } \\
\text { respiratory failure in COPD }\end{array}$ & $\begin{array}{l}\text { The aim of the study was to evaluate the } \\
\text { adequacy of diagnosis and management of } \\
\text { respiratory failure (RF) in COPD }\end{array}$ & $\begin{array}{l}\text { Quantitative } \\
\text { (Retrospective } \\
\text { clinical audit) }\end{array}$ & Canada & $\begin{array}{l}\mathrm{N}=130 \\
\text { patients }\end{array}$ & $\begin{array}{l}\text { Accurate diagnosis and categorisation are } \\
\text { essential in implementing quality } \\
\text { improvement measures based on clinical } \\
\text { audits }\end{array}$ & $\begin{array}{l}\text { Clinical pathways for uniform oxygen } \\
\text { management }\end{array}$ \\
\hline $\begin{array}{l}\text { 7) Migone } \\
2015^{20}\end{array}$ & $\begin{array}{l}\text { Patients Hospitalised with an } \\
\text { Acute Exacerbation of } \\
\text { COPD }^{\mathrm{a}} \text { Is There a Need for a } \\
\text { Discharge Bundle of Care }\end{array}$ & $\begin{array}{l}\text { Identify the proportion of those patients } \\
\text { admitted with AECOPD who had } \\
\text { received a number of recommended } \\
\text { interventions by the time of discharge. A } \\
\text { secondary aim of the study was to } \\
\text { examine the association between the } \\
\text { delivery of recommended interventions } \\
\text { and care under a respiratory physician } \\
\text { and a respiratory clinical nurse specialist } \\
\text { (RCNS) }\end{array}$ & $\begin{array}{l}\text { Quantitative } \\
\text { (Retrospective } \\
\text { chart audit) }\end{array}$ & Ireland & $\begin{array}{l}\mathrm{N}=174 \\
\text { patients }\end{array}$ & $\begin{array}{l}\text { Lack of knowledge of the benefits of } \\
\text { some interventions (pulmonary } \\
\text { rehabilitation particularly for non- } \\
\text { respiratory physicians) } \\
\text { Difficulty in implementing } \\
\text { recommendations from guidelines where } \\
\text { complex behaviour change is required } \\
\text { (written self-management plans, may be a } \\
\text { barrier) } \\
\text { Perception amongst hospital doctors that } \\
\text { some interventions are the responsibility } \\
\text { of general practitioners. This has been } \\
\text { reported in the literature in relation to } \\
\text { smoking cessation and vaccination }\end{array}$ & $\begin{array}{l}\text { Electronic reminders \& bundles of care. } \\
\text { Discharge bundle of care reduced } \\
\text { readmissions for COPD and increased } \\
\text { adherence to guidelines bundle of care. } \\
\text { Discharge bundle improved referral for } \\
\text { smoking cessation assistance from } 18.2 \% \\
\text { to } 100 \% \text { and review of inhaler technique } \\
\text { increased from } 59.1 \% \text { to } 91.2 \% \text { of } \\
\text { admissions. } \\
\text { Care bundle impact on pulmonary } \\
\text { rehabilitation referral rates rose from } \\
13.6 \% \text { to } 68 \% \text {. Similar improvements } \\
\text { were seen in administration of self- } \\
\text { management plans } \\
\text { Training of medical staff of the benefits of } \\
\text { interventions for patients with COPD is } \\
\text { also important }\end{array}$ \\
\hline
\end{tabular}




\begin{tabular}{|c|c|c|c|c|c|c|c|}
\hline $\begin{array}{l}\text { 8) Overington } \\
2014^{12}\end{array}$ & $\begin{array}{l}\text { Implementing clinical } \\
\text { guidelines for chronic } \\
\text { obstructive pulmonary disease: } \\
\text { barriers and solutions }\end{array}$ & $\begin{array}{l}\text { This review explores these critical issues, } \\
\text { gaining insight from efforts in clinical } \\
\text { guidelines for other chronic diseases, and } \\
\text { applying these principles to improving } \\
\text { uptake of the COPD guidelines amongst } \\
\text { clinicians }\end{array}$ & $\begin{array}{l}\text { Literature } \\
\text { Review }\end{array}$ & Australia & $\mathrm{N}=5$ studies & $\begin{array}{l}\text { Low awareness } \\
\text { Clinician knowledge of COPD } \\
\text { management is low worldwide } \\
\text { Time constraints } \\
\text { Disparity in guideline awareness }\end{array}$ & $\begin{array}{l}\text { Targeted health professional education } \\
\text { Clinical decision-making algorithms } \\
\text { Electronic reminders at clinical points } \\
\text { Continuous quality assurance projects } \\
\text { Supportive clinical behavior enablers } \\
\text { Brief summaries of guideline in clinical } \\
\text { areas } \\
\text { Direct mailing guidelines to Clinicians } \\
\text { Education sessions with didactic and } \\
\text { interactive content } \\
\text { Electronic health records } \\
\text { Readily accessible guidelines } \\
\text { Multifaceted implementation programmes } \\
\text { (pamphlets, reminders and meetings) } \\
\text { Point of care checklists (electronic) }\end{array}$ \\
\hline $\begin{array}{l}\text { 9) Pozo- } \\
\text { Rodrã-guez } \\
2012^{54}\end{array}$ & $\begin{array}{l}\text { Clinical audit of COPD } \\
\text { patients requiring hospital } \\
\text { admissions in Spain: } \\
\text { AUDIPOC }{ }^{2} \text { study }\end{array}$ & $\begin{array}{l}\text { AUDIPOC is a nationwide clinical audit } \\
\text { that describes the characteristics, } \\
\text { interventions and outcomes of patients } \\
\text { admitted to Spanish hospitals because of } \\
\text { an acute exacerbation of chronic } \\
\text { obstructive pulmonary disease } \\
\text { (AECOPD), assessing the compliance of } \\
\text { these parameters with current } \\
\text { international guidelines }\end{array}$ & $\begin{array}{l}\text { Prospective } \\
\text { cross-sectional } \\
\text { study }\end{array}$ & Spain & $\begin{array}{l}\mathrm{N}=5178 \\
\text { patients (225 } \\
\text { participating } \\
\text { hospitals in a } \\
\text { national } \\
\text { audit) }\end{array}$ & $\begin{array}{l}\text { Variability of care at the hospital level and } \\
\text { non-compliance with recommendations } \\
\text { regarding diagnosis or in-hospital } \\
\text { treatment } \\
\text { Level of information included in the final } \\
\text { discharge report did not include } \\
\text { recommendations related to general } \\
\text { health practices and lifestyle } \\
\text { improvements and were provided to only } \\
50 \% \text { patients } \\
\text { Minimal interventions aimed at promoting } \\
\text { smoking cessation, an active lifestyle } \\
\text { (including rehabilitation prescription) and/ } \\
\text { influenzas or pneumococcal vaccination }\end{array}$ & $\begin{array}{l}\text { The association of access to electronicl } \\
\text { digital information with the number of } \\
\text { interim and definite cases suggests that } \\
\text { the use of information technologies may } \\
\text { increase the identification of cases and, } \\
\text { possibly, improve the audit process }\end{array}$ \\
\hline
\end{tabular}

(Continued) 
Table 2 (Continued).

\begin{tabular}{|c|c|c|c|c|c|c|c|}
\hline $\begin{array}{l}\text { Included } \\
\text { Studies } \\
\text { References }\end{array}$ & Title & Aims & Methods & Country & $\begin{array}{l}\text { Sample } \\
\text { Size }\end{array}$ & Barriers & $\begin{array}{l}\text { Solutions/Research } \\
\text { Recommendations }\end{array}$ \\
\hline $\begin{array}{l}\text { 10) Pretto } \\
2012^{52}\end{array}$ & $\begin{array}{l}\text { Multicenter audit of inpatient } \\
\text { management of acute } \\
\text { exacerbations of chronic } \\
\text { obstructive pulmonary disease: } \\
\text { comparison with clinical } \\
\text { guidelines }\end{array}$ & $\begin{array}{l}\text { Document variability and identify gaps } \\
\text { from guidelines in management practices } \\
\text { to allow targeted interventions to be } \\
\text { developed to improve quality of care }\end{array}$ & $\begin{array}{l}\text { Retrospective } \\
\text { medical record } \\
\text { audit }\end{array}$ & Australia & $\begin{array}{l}\mathrm{N}=221 \\
\text { patients }\end{array}$ & $\begin{array}{l}\text { Non provision of non-invasive ventilation } \\
\text { (NIV), due to medical decision to not } \\
\text { escalate treatment, patient responding } \\
\text { well to medical treatment or patient } \\
\text { refusal } \\
\text { Low respiratory specialist referral and } \\
\text { pulmonary rehabilitation referrals } \\
\text { Low level of support to implement } \\
\text { smoking cessation in public hospitals } \\
\text { Lack of standard communication } \\
\text { regarding pulmonary function testing } \\
\text { Low utilisation of ABG data to utilise } \\
\text { NIV } \\
\text { Lack of previous experience with NIV } \\
\text { initiation. Lack of staff education on NIV } \\
\text { More than quarter discharged patient } \\
\text { from rural hospital were readmitted } \\
\text { within } 28 \text { days } \\
\text { Low concordance to COPD } \\
\text { management guidelines }\end{array}$ & $\begin{array}{l}\text { Targeted educational intervention for } \\
\text { utilisation of NIV } \\
\text { Target specific practices in the } \\
\text { development } \\
\text { of AECOPD } \\
\text { management policies }\end{array}$ \\
\hline $\begin{array}{l}\text { 11) Roberts } \\
2013^{22}\end{array}$ & $\begin{array}{l}\text { European hospital adherence } \\
\text { to GOLD }{ }^{\mathrm{a}} \text { recommendations } \\
\text { for chronic obstructive } \\
\text { pulmonary disease (COPD) } \\
\text { exacerbation admissions }\end{array}$ & $\begin{array}{l}\text { Understanding how European care of } \\
\text { chronic obstructive pulmonary disease } \\
\text { (COPD) admissions vary against guideline } \\
\text { standards provide an opportunity to } \\
\text { target appropriate quality improvement } \\
\text { interventions }\end{array}$ & $\begin{array}{l}\text { Retrospective } \\
\text { case note audit }\end{array}$ & $\begin{array}{l}\text { Austria, Belgium, } \\
\text { Croatia, Greece, } \\
\text { Malta, Poland, } \\
\text { Republic of Ireland, } \\
\text { Romania, Spain, } \\
\text { Switzerland Turkey } \\
\text { and the United } \\
\text { Kingdom }\end{array}$ & $\begin{array}{l}\mathrm{N}=16018 \\
\text { patients (384 } \\
\text { hospitals) }\end{array}$ & $\begin{array}{l}\text { Unavailability of spirometry test results } \\
\text { despite previous admissions } \\
\text { patients not having an ABG test } \\
\text { documented also received } \\
\text { Oxygen. } \\
\text { Inappropriate antibiotic prescription }\end{array}$ & $\begin{array}{l}\text { Primary and secondary care spirometry } \\
\text { results access } \\
\text { Understanding care quality and } \\
\text { deficiencies provide opportunities for } \\
\text { targeted interventions that could produce } \\
\text { significant patient benefits }\end{array}$ \\
\hline $\begin{array}{l}\text { 12) Sandhu } \\
2013^{50}\end{array}$ & $\begin{array}{l}\text { Variations in the management } \\
\text { of acute exacerbations of } \\
\text { chronic obstructive pulmonary } \\
\text { disease }\end{array}$ & $\begin{array}{l}\text { Evaluate adherence to current guidelines } \\
\text { across different physician groups and } \\
\text { patient outcomes were assessed }\end{array}$ & $\begin{array}{l}\text { A retrospective } \\
\text { chart review }\end{array}$ & Canada & $\begin{array}{l}\mathrm{N}=293 \\
\text { patients }\end{array}$ & $\begin{array}{l}\text { Lack of physician awareness of guidelines } \\
\text { Care gaps between general internists, } \\
\text { respiratory physicians and hospitals }\end{array}$ & $\begin{array}{l}\text { Risk stratification and appropriate } \\
\text { optimization of maintenance therapy at } \\
\text { the time of discharge } \\
\text { Cross fertilisation of knowledge by } \\
\text { respiratory physicians to other } \\
\text { departments }\end{array}$ \\
\hline
\end{tabular}




\begin{tabular}{|c|c|c|c|c|c|c|c|}
\hline $\begin{array}{l}\text { 13) Seys } \\
\text { 2017 }\end{array}$ & $\begin{array}{l}\text { An International Study of } \\
\text { Adherence to Guidelines for } \\
\text { Patients Hospitalised with a } \\
\text { COPD }^{\mathrm{a}} \text { Exacerbation }\end{array}$ & $\begin{array}{l}\text { The aim of this study is to perform an } \\
\text { importance-performance analysis as an } \\
\text { approach for prioritisation of } \\
\text { interventions by linking guideline } \\
\text { adherence rates to expert consensus on } \\
\text { the importance for follow /through in } \\
\text { hospital management of COPD } \\
\text { exacerbation }\end{array}$ & $\begin{array}{l}\text { Cluster } \\
\text { randomised } \\
\text { controlled trial }\end{array}$ & Belgium & $\begin{array}{l}\mathrm{N}=378 \\
\text { patients }\end{array}$ & $\begin{array}{l}\text { Lowest adherence to guidelines can } \\
\text { mainly be seen for indicators related to } \\
\text { patient education (such as oxygen } \\
\text { therapy), nutritional assessment, } \\
\text { pulmonary rehabilitation and discharge } \\
\text { management. } \\
\text { Managerial issues, eg, communication gap } \\
\text { between management and prescribers } \\
\text { lack of persuasion from the } \\
\text { administration, and scientific issues, eg, } \\
\text { faulty guideline development } \\
\text { Process or guideline is not-up-to-date, } \\
\text { relevant or disagreement with the } \\
\text { guideline } \\
\text { Guideline is too complicated and } \\
\text { difference in clinical scenario to the ones } \\
\text { mentioned in guidelines }\end{array}$ & $\begin{array}{l}\text { Performance analysis to develop quality } \\
\text { framework for systematic follow up of } \\
\text { guideline recommendations } \\
\text { Care pathways can be used as a } \\
\text { framework for clinical interventions as } \\
\text { they are based on evidence }\end{array}$ \\
\hline $\begin{array}{l}\text { 14) Seys } \\
\text { 2018 } 8^{53}\end{array}$ & $\begin{array}{l}\text { Teamwork and Adherence to } \\
\text { Recommendations Explain the } \\
\text { Effect of a Care Pathway on } \\
\text { Reduced 30-day Readmission } \\
\text { for Patients with a COPD } \\
\text { Exacerbation }\end{array}$ & $\begin{array}{l}\text { This study aimed to increase our } \\
\text { understanding of processes that underlie } \\
\text { the effect of care pathway } \\
\text { implementation on reduced 30-day } \\
\text { readmission rate. }\end{array}$ & $\begin{array}{l}\text { Cluster } \\
\text { randomised trial }\end{array}$ & $\begin{array}{l}\text { Belgium } \\
\text { Italy } \\
\text { Portugal }\end{array}$ & $\begin{array}{l}\mathrm{N}=257 \\
\text { patients (19 } \\
\text { hospitals) }\end{array}$ & $\begin{array}{l}\text { Staff burn out } \\
\text { Team climate for innovation }\end{array}$ & $\begin{array}{l}\text { Care pathway implementation was } \\
\text { significantly associated with better } \\
\text { guideline adherence and reduced 30-day } \\
\text { readmission. } \\
\text { Clinical interventions Priority indicators } \\
\text { for departments }\end{array}$ \\
\hline $\begin{array}{l}\text { 15) Sha } \\
2019^{10}\end{array}$ & $\begin{array}{l}\text { Hospitalised exacerbations of } \\
\text { chronic obstructive pulmonary } \\
\text { disease: adherence to guideline } \\
\text { recommendations in an } \\
\text { Australian teaching hospital }\end{array}$ & $\begin{array}{l}\text { To examine current practice in } \\
\text { management of COPD' exacerbations at } \\
\text { an } \\
\text { Australian teaching hospital and to } \\
\text { compare with COPD-X Plan } \\
\text { recommendations }\end{array}$ & $\begin{array}{l}\text { Retrospective } \\
\text { chart audit }\end{array}$ & Australia & $\begin{array}{l}\mathrm{N}=134 \\
\text { patients }\end{array}$ & $\begin{array}{l}\text { Reduced awareness of guidelines } \\
\text { especially among junior doctors } \\
\text { Venous blood gas (VBG) being an } \\
\text { unreliable substitute for arterial blood gas } \\
\text { (ABG) assessing presence of } \\
\text { hypercapneic respiratory failure may be } \\
\text { due to patient refusal, clinician concern } \\
\text { about patient tolerability and easier } \\
\text { technique for clinicians } \\
\text { Time poor clinicians may overlook } \\
\text { smoking and immunisation history } \\
\text { NIV' provided unnecessarily to patients } \\
\text { with adequate oxygenation } \\
\text { Antibiotics administration despite normal } \\
\text { white cell count } \\
\text { Use of corticosteroids without indication } \\
\text { Underutilisation of pulmonary rehab } \\
\text { Reduced vaccination recommendations }\end{array}$ & Electronic alerts and care sets \\
\hline
\end{tabular}


Table 2 (Continued)

\begin{tabular}{|c|c|c|c|c|c|c|c|}
\hline $\begin{array}{l}\text { Included } \\
\text { Studies } \\
\text { References }\end{array}$ & Title & Aims & Methods & Country & $\begin{array}{l}\text { Sample } \\
\text { Size }\end{array}$ & Barriers & $\begin{array}{l}\text { Solutions/Research } \\
\text { Recommendations }\end{array}$ \\
\hline $\begin{array}{l}\text { l6) } \\
\text { Wijayaratne } \\
2013^{36}\end{array}$ & $\begin{array}{l}\text { Differences in care between } \\
\text { general } \\
\text { medicine and respiratory } \\
\text { specialists } \\
\text { in the management of patients } \\
\text { hospitalised for acute } \\
\text { exacerbations of chronic } \\
\text { obstructive pulmonary disease }\end{array}$ & $\begin{array}{l}\text { The aims of this study were to firstly } \\
\text { examine the differences in AECOPD } \\
\text { management of general medicine } \\
\text { practitioners (GMP) and Respiratory } \\
\text { specialist (RS) and secondly compare } \\
\text { their care to national COPD guidelines }\end{array}$ & $\begin{array}{l}\text { A retrospective } \\
\text { review }\end{array}$ & Australia & $\begin{array}{l}N=169 \\
\text { patients }\end{array}$ & $\begin{array}{l}\text { Inadequate utilisation of NIV despite } \\
\text { meeting guideline criteria } \\
\text { Differences in medication prescription } \\
\text { between general medicine physicians and } \\
\text { Respiratory specialist } \\
\text { GMP performed fewer investigations and } \\
\text { provided less pharmacological } \\
\text { management while in hospital compared } \\
\text { to RS } \\
\text { Lower rates of referral to pulmonary } \\
\text { rehabilitation s low } \\
\text { awareness, low support for rehabilitation } \\
\text { at multiple levels, lack of time and a } \\
\text { perceived difficult referral process } \\
\text { GMP did not prescribe short-acting } \\
\text { beta-agonists (SABA }) \text {, long-acting } \\
\text { anti-cholinergic, combination LABA }{ }^{a} / I C S^{a} \\
\text { and systemic steroids as frequently as RS } \\
\text { and instead prescribed short-acting } \\
\text { anti-cholinergic more frequently. }\end{array}$ & $\begin{array}{l}\text { Further research to understand reasons } \\
\text { behind poor prescription of NIV for } \\
\text { eligible patients }\end{array}$ \\
\hline $\begin{array}{l}\text { 17) Vanhaecht } \\
2016^{34}\end{array}$ & $\begin{array}{l}\text { Impact of a care pathway for } \\
\text { COPD }^{\mathrm{a}} \text { on adherence to } \\
\text { guidelines and hospital } \\
\text { readmission: a cluster } \\
\text { randomized trial }\end{array}$ & $\begin{array}{l}\text { The primary aim of this study was to } \\
\text { evaluate whether implementation of a } \\
\text { care pathway (CP) for COPD improves } \\
\text { the } 6 \text { months readmission rate }\end{array}$ & $\begin{array}{l}\text { Pragmatic } \\
\text { cluster } \\
\text { randomised } \\
\text { controlled trial }\end{array}$ & $\begin{array}{l}\text { Belgium, Ireland, } \\
\text { Italy and Portugal }\end{array}$ & $\begin{array}{l}\mathrm{N}=174 \\
\text { patients (II } \\
\text { hospitals) }\end{array}$ & $\begin{array}{l}\text { Nonpharmacological management } \\
\text { observed to be suboptimal particularly } \\
\text { education required care } \\
\text { recommendations such as smoking } \\
\text { cessation, inhaler technique and } \\
\text { pulmonary rehab }\end{array}$ & $\begin{array}{l}\text { Care pathway implementation } \\
\text { significantly lowered 30-day readmission } \\
\text { rate and improved performance on } \\
\text { process indicators } \\
\text { Clinical audits and continuous quality } \\
\text { improvements to target and improve low } \\
\text { performing indicators }\end{array}$ \\
\hline
\end{tabular}




\begin{tabular}{|c|c|c|c|c|c|c|c|}
\hline $\begin{array}{l}\text { 18) Susanto } \\
2015^{32}\end{array}$ & $\begin{array}{l}\text { Assessing the use of initial } \\
\text { oxygen therapy in chronic } \\
\text { obstructive pulmonary disease } \\
\text { patients: a retrospective audit } \\
\text { of pre-hospital and hospital } \\
\text { emergency management }\end{array}$ & $\begin{array}{l}\text { Assess the use of } \mathrm{O}_{2} \text { therapy and } \mathrm{FiO}_{2} \text { in } \\
\text { the emergency management of patients } \\
\text { with a known diagnosis of } \mathrm{COPD}^{\mathrm{a}}\end{array}$ & $\begin{array}{l}\text { Retrospective } \\
\text { audit }\end{array}$ & Australia & $\begin{array}{l}\mathrm{N}=150 \\
\text { patients }\end{array}$ & $\begin{array}{l}\text { High-flow oxygen is used for the initial } \\
\text { treatment of COPD exacerbations when } \\
\text { only 53\% patients were recognised to } \\
\text { have COPD } \\
\text { A lack of recognition of COPD high flow } \\
\text { oxygen initiated in ambulances continued } \\
\text { in ED in spite of down titration } \\
\text { Blood gas measurements were } \\
\text { performed, but there was a high } \\
\text { proportion of VBG measurements rather } \\
\text { than the recommended arterial analysis }\end{array}$ & $\begin{array}{l}\text { Larger, prospective studies would be } \\
\text { required to confirm the possible harm of } \\
\text { un-titrated oxygen approach in COPD" } \\
\text { Patients } \\
\text { The implementation of current oxygen } \\
\text { guidelines for use in the pre-hospital } \\
\text { setting and education of those who are } \\
\text { involved in treating COPD patients in } \\
\text { emergency care and other situations may } \\
\text { reduce the risk of complications in } \\
\text { COPD patients. } \\
\text { Developing oxygen administration } \\
\text { guidelines depending on the initial SpO2 } \\
\text { would be useful as this could potentially } \\
\text { prevent administration of high- flow } \\
\text { Oxygen as first line treatment. } \\
\text { Education of patients regarding their } \\
\text { diagnosis of COPD', the importance of } \\
\text { alerting ambulance and medical personnel } \\
\text { to the diagnosis and the provision of a } \\
\text { medical alert bracelet or oxygen alert } \\
\text { card, especially in those with known } \\
\text { hypercapnia. The utilisation of a dedicated } \\
\text { oxygen prescription chart, which has } \\
\text { been used in some hospitals, may also be } \\
\text { of some beneffit. }\end{array}$ \\
\hline $\begin{array}{l}\text { 19) } \\
\text { Brownridge } \\
2017^{47}\end{array}$ & $\begin{array}{l}\text { Retrospective audit of } \\
\text { antimicrobial prescribing } \\
\text { practices for acute } \\
\text { exacerbations of chronic } \\
\text { obstructive pulmonary } \\
\text { diseases in a large regional } \\
\text { hospital }\end{array}$ & $\begin{array}{l}\text { Evaluate the antibiotic prescribing } \\
\text { practices in acute exacerbations of } \\
\text { chronic obstructive pulmonary disease } \\
\text { (AECOPD') patients, and to compare the } \\
\text { differences in clinical outcomes (primarily } \\
\text { mean length of stay and the rate of } \\
\text { unplanned readmissions) between } \\
\text { patients who received broad vs narrow- } \\
\text { spectrum antibiotic }\end{array}$ & $\begin{array}{l}\text { Implementation } \\
\text { audit }\end{array}$ & Australia & $\begin{array}{l}\mathrm{N}=130 \\
\text { patients }\end{array}$ & $\begin{array}{l}\text { Inappropriate use of antimicrobial agents } \\
\text { representing a modiffable factor } \\
\text { responsible for driving antimicrobial } \\
\text { resistance Only Ten per cent of patients } \\
\text { received guideline concordant } \\
\text { antimicrobial therapy The single most } \\
\text { common reason for non-compliance with } \\
\text { current guidelines was the use of dual } \\
\text { antibiotic therapy }\end{array}$ & 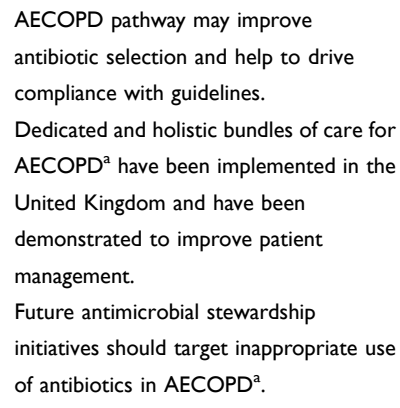 \\
\hline $\begin{array}{l}\text { 20) } \mathrm{kim} \\
\text { 2019 } 9^{30}\end{array}$ & $\begin{array}{l}\text { Adherence to the GOLD } \\
\text { Guideline in COPD } \\
\text { management of South } \\
\text { Korea: Findings from KOCOSS } \\
\text { Study 2011-2018 }\end{array}$ & $\begin{array}{l}\text { Examine the adherence to the GOLD } \\
\text { guidelines, we examined the patterns of } \\
\text { prescribed medication in COPD patients } \\
\text { from } 2011 \text { to } 2018 \text {. }\end{array}$ & Cohort study & Korea & $\begin{array}{l}\mathrm{N}=1818 \\
\text { patients }\end{array}$ & $\begin{array}{l}\text { The common type of inappropriate } \\
\text { COPD treatment is overtreatment, with } \\
\text { inhaled corticosteroid (ICSa) containing } \\
\text { regimens Low rate of guideline adherence } \\
\text { with } 61.5 \% \text { for } 2011 \text { and } 49.6 \% \text { for } 2017\end{array}$ & $\begin{array}{l}\text { Standardization of COPD } \\
\text { pharmacological treatment utilising } \\
\text { GOLD guidelines } \\
\text { Better implementation strategy to } \\
\text { optimize the use of these guidelines a }\end{array}$ \\
\hline
\end{tabular}

(Continued) 
Table 2 (Continued).

\begin{tabular}{|c|c|c|c|c|c|c|c|}
\hline $\begin{array}{l}\text { Included } \\
\text { Studies } \\
\text { References }\end{array}$ & Title & Aims & Methods & Country & $\begin{array}{l}\text { Sample } \\
\text { Size }\end{array}$ & Barriers & $\begin{array}{l}\text { Solutions/Research } \\
\text { Recommendations }\end{array}$ \\
\hline $\begin{array}{l}\text { 21) Kelly } \\
2019^{11}\end{array}$ & $\begin{array}{l}\text { Get with the guidelines: } \\
\text { management of chronic } \\
\text { obstructive pulmonary disease } \\
\text { in emergency departments in } \\
\text { Europe and Australasia is sub- } \\
\text { optimal }\end{array}$ & $\begin{array}{l}\text { To determine compliance with guideline } \\
\text { recommendations for patients treated for } \\
\text { COPD in ED in Europe (EUR) and South } \\
\text { East Asia/Australasia (SEA) and to } \\
\text { compare management and outcome }\end{array}$ & $\begin{array}{l}\text { Prospective } \\
\text { cohort study }\end{array}$ & $\begin{array}{l}\text { Australia } \\
\text { Europe } \\
\text { South-east Asia }\end{array}$ & $\begin{array}{l}\mathrm{N}=80 \mathrm{I} \\
\text { patients }\end{array}$ & $\begin{array}{l}\text { Compliance with guideline recommended } \\
\text { treatments, in particular administration of } \\
\text { corticosteroids and NIV', was sub- } \\
\text { optimal in both regions } \\
\text { The proportion of patients with acidosis } \\
\text { who received treatment with NIV } \\
\text { was also lower than expected, despite } \\
\text { level I evidence that it improves } \\
\text { outcome.I lack of awareness of the } \\
\text { evidence, lack of availability of the } \\
\text { required equipment in ED and lack of } \\
\text { appropriately trained staff to undertake } \\
\text { this therapy safely in ED } \\
\text { Patient declining NIV or clinician } \\
\text { underestimating severity of COPD } \\
\text { The evidence suggests there may be a } \\
\text { disjunct between ward-based pathways } \\
\text { and ED }{ }^{\mathrm{a}} \text { pathways for this patient group, a } \\
\text { gap that should be closed lack of } \\
\text { awareness of the evidence, the cognitive } \\
\text { overload associated with ED } \\
\text { practice, time constraints in ED } \\
\text { distraction and competing patient } \\
\text { priorities as several patients, high } \\
\text { turnover of ED }{ }^{\mathrm{a}} \text { staff making it difficult to } \\
\text { ensure that all staff are educated in } \\
\text { evidence-based recommendations and } \\
\text { recent change }\end{array}$ & $\begin{array}{l}\text { Individual health services local audit to } \\
\text { inform individual health services and } \\
\text { hopefully encourage them to audit their } \\
\text { own practice and implement quality } \\
\text { improvement activities with an emphasis } \\
\text { on the identified gaps } \\
\text { COPD proforma or checklist use of } \\
\text { clinical informatics systems, computer- } \\
\text { assisted decision support Disease specific } \\
\text { ED short stay unit pathways and access } \\
\text { to appropriate follow-up care (such as } \\
\text { primary care or specialist clinics, disease } \\
\text { specific outreach services, encourage } \\
\text { smoking cessation }\end{array}$ \\
\hline
\end{tabular}




\begin{tabular}{|c|c|c|c|c|c|c|c|}
\hline $\begin{array}{l}\text { 22) Harrison } \\
2017^{37}\end{array}$ & $\begin{array}{l}\text { Inappropriate inhaled } \\
\text { corticosteroid prescribing in } \\
\text { chronic obstructive pulmonary } \\
\text { disease patients }\end{array}$ & $\begin{array}{l}\text { This study quantified the proportion of } \\
\text { patients with COPD on } \mathrm{CSS}^{\mathrm{a}} \text { treatment } \\
\text { despite a post-bronchodilator } \mathrm{FEVI}^{\mathrm{a}} \geq \\
\text { 50\%. }\end{array}$ & $\begin{array}{l}\text { Retrospective } \\
\text { medical audit }\end{array}$ & Australia & $\begin{array}{l}\mathrm{N}=707 \\
\text { patients }\end{array}$ & $\begin{array}{l}\text { Significant discordance exists between } \\
\text { guideline recommendations and inhaler } \\
\text { prescription over-prescription of ICS in } \\
\text { COPD². }^{2}\end{array}$ & $\begin{array}{l}\text { COPD-X and the Pharmaceutical Benefit } \\
\text { Scheme recommend that the } \\
\text { introduction of inhaled corticosteroid } \\
\text { (ICS) and long-acting beta-agonist } \\
\text { combinations (LABA) should be reservec } \\
\text { for patients with a post bronchodilator } \\
\text { FEVI less than } 50 \% \text { predicted and those } \\
\text { who experience more than two } \\
\text { exacerbations in } 12 \text { months Encourage } \\
\text { guideline education and prescribing within } \\
\text { guidelines }\end{array}$ \\
\hline $\begin{array}{l}\text { 23) Jouleh } \\
\text { 2018 }\end{array}$ & $\begin{array}{l}\text { Guideline adherence in } \\
\text { hospital recruited and } \\
\text { population based COPD } \\
\text { patients }\end{array}$ & $\begin{array}{l}\text { Estimate and compare the guideline } \\
\text { adherence to COPD treatment in } \\
\text { general population-based and hospital- } \\
\text { recruited COPD patients, and find } \\
\text { possible predictors of guideline } \\
\text { adherence }\end{array}$ & $\begin{array}{l}\text { Prospective } \\
\text { observational } \\
\text { cohort study }\end{array}$ & Norway & $\begin{array}{l}N=(\text { cohort } \\
I-90) \\
N=(\text { cohort } \\
2-245)\end{array}$ & $\begin{array}{l}\text { Adherence to guidelines were } \\
\text { significantly lower in cohort treated by } \\
\text { general physicians in diagnostic, } \\
\text { pharmacological and non-pharmacological } \\
\text { management } \\
\text { Educational institutions not utilising } \\
\text { COPD guidelines particularly with } \\
\text { nurses and physiotherapists }\end{array}$ & $\begin{array}{l}\text { Reliable and regularly updated guidelines } \\
\text { are therefore, very valuable for clinicians } \\
\text { and help them provide the best care for } \\
\text { their patients at any time. } \\
\text { Possible establishment of incentives for } \\
\text { the health care personnel who do adhere } \\
\text { to the guidelines Accessible guidelines for } \\
\text { healthcare workers, drug devises that } \\
\text { facilitates compliance, accessible } \\
\text { rehabilitation facilities, and vaccination } \\
\text { programmes to ensure that COPD } \\
\text { patients are offered the best care } \\
\text { available. }\end{array}$ \\
\hline
\end{tabular}

(Continued) 
Table 2 (Continued).

\begin{tabular}{|c|c|c|c|c|c|c|c|}
\hline $\begin{array}{l}\text { Included } \\
\text { Studies } \\
\text { References }\end{array}$ & Title & Aims & Methods & Country & $\begin{array}{l}\text { Sample } \\
\text { Size }\end{array}$ & Barriers & $\begin{array}{l}\text { Solutions/Research } \\
\text { Recommendations }\end{array}$ \\
\hline $\begin{array}{l}\text { 24) Desalu } \\
\text { 201 } 13^{29}\end{array}$ & $\begin{array}{l}\text { Guideline adherence in } \\
\text { hospital recruited and } \\
\text { population based COPD } \\
\text { patients }\end{array}$ & $\begin{array}{l}\text { To assess physicians' understanding, } \\
\text { adherence, and barriers to } \\
\text { implementation of GOLD guidelines in } \\
\text { Nigeria }\end{array}$ & $\begin{array}{l}\text { Cross-sectional } \\
\text { study }\end{array}$ & Nigeria & $\begin{array}{l}\mathrm{N}=156 \\
\text { physicians }\end{array}$ & $\begin{array}{l}\text { Lack of familiarity was cited as the most } \\
\text { common barrier to adherence to the } \\
\text { guidelines } \\
\text { Lack of awareness, non-familiarity, } \\
\text { outcome of expectancy, time constraints, } \\
\text { and non-agreement with } \\
\text { recommendation. } \\
\text { Environmental, and guideline-related } \\
\text { factors which are beyond the control of } \\
\text { physicians } \\
\text { Lack of knowledge of spirometry } \\
\text { interpretation may also be associated } \\
\text { with the low utilisation as only one- } \\
\text { quarter (26.9\%) of the respondents could } \\
\text { correctly make a spirometric diagnosis of } \\
\text { COPD } \\
\text { Health facilities (specialist and medical } \\
\text { equipment) are inadequate in Nigeria, } \\
\text { especially in rural areas. Most of the } \\
\text { tertiary hospitals are located in the urban } \\
\text { areas, of which only } 29.4 \% \text { have a } \\
\text { spirometer Political commitment and } \\
\text { resources are also lacking, and the } \\
\text { allocation of a budget and human } \\
\text { resources for the prevention and } \\
\text { management of COPD is not a priority } \\
\text { Low utilisation of pulmonary } \\
\text { rehabilitation may be attributed to lack of } \\
\text { human resources including specialists in } \\
\text { pulmonary rehabilitation, infrastructure, } \\
\text { and establishment of a well-equipped } \\
\text { pulmonary rehabilitation unit in most } \\
\text { hospitals in Nigeria. Poor awareness of its } \\
\text { impact on the outcome of management, } \\
\text { non--vailability, and affordability of the } \\
\text { vaccines }\end{array}$ & $\begin{array}{l}\text { Frequent expossure of more senior } \\
\text { doctors to the recommendations } \\
\text { of the guidelines from several sources of } \\
\text { continuing medical } \\
\text { education (CME) and publications. } \\
\text { World } \\
\text { Spirometry Day should be used to } \\
\text { increase the awareness and use of } \\
\text { Spirometry } \\
\text { Continuing medical education (CME) on } \\
\text { these } \\
\text { modalities of therapy. } \\
\text { Physicians should collaborate with } \\
\text { hospital } \\
\text { authorities to establish smoking cessation } \\
\text { teams and pulmonary } \\
\text { rehabilitation units. } \\
\text { The pharmaceutical industry can also } \\
\text { contribute } \\
\text { by making available cheaper vaccines for } \\
\text { COPD patients } \\
\text { Educational interventions are required to } \\
\text { achieve optimal care for COPD patients. }\end{array}$ \\
\hline
\end{tabular}




\begin{tabular}{|c|c|c|c|c|c|c|c|}
\hline $\begin{array}{l}\text { 25) Tang } \\
2014^{38}\end{array}$ & $\begin{array}{l}\text { Level of adherence to the } \\
\text { GOLD } \text { strategy document for } \\
\text { management of patients } \\
\text { admitted to hospital with an } \\
\text { acute } \\
\text { exacerbation of COPD }\end{array}$ & $\begin{array}{l}\text { Evaluate the level of adherence among } \\
\text { health professionals } \\
\text { to GOLD }\end{array}$ & $\begin{array}{l}\text { Retrospective } \\
\text { audit }\end{array}$ & Australia & $\begin{array}{l}\mathrm{N}=240 \\
\text { patients }\end{array}$ & $\begin{array}{l}\text { Over prescription of antibiotics and } \\
\text { oxygen therapy } \\
\text { Poor adherence to steroids and } \\
\text { antibiotics } \\
\text { Non-pharmacological management such } \\
\text { pulmonary rehabilitation and smoking } \\
\text { cessation } \\
\text { Factors such as time } \\
\text { constraints and lack of awareness about } \\
\text { resources } \\
\text { may be the reasons for the poor } \\
\text { adherence. } \\
\text { Reduction in hospital beds puts pressure } \\
\text { to provide subboptimal treatment } \\
\text { Lack of clinical advocacy by senior } \\
\text { clinicians } \\
\text { Ambiguity in recommendations from } \\
\text { GOLD recommendations }\end{array}$ & $\begin{array}{l}\text { Clinical practice review to improve } \\
\text { nonpharmacological management } \\
\text { Improving environmental resources, } \\
\text { promotion campaigns } \\
\text { Targeted educational sessions specialised } \\
\text { to each discipline } \\
\text { Interactive educational tools, specific cue } \\
\text { cards in clinical practice and presence of } \\
\text { hospital clinical champions } \\
\text { Improved communication between } \\
\text { hospitals and primary care practitioners } \\
\text { Clarity and communication by senior } \\
\text { clinicians to address ambiguity to choose } \\
\text { of evidence-based practice }\end{array}$ \\
\hline 26) Ta $2011^{43}$ & $\begin{array}{l}\text { Management of chronic } \\
\text { obstructive pulmonary disease } \\
\text { in } \\
\text { Australia after the publication } \\
\text { of national guidelines }\end{array}$ & $\begin{array}{l}\text { To evaluate } \mathrm{COPD}^{\mathrm{a}} \text { patient adherence to } \\
\text { treatment recommendations and } \\
\text { healthcare provider adherence to the } \\
\text { COPD }-\mathrm{X} \text { Plan }\end{array}$ & $\begin{array}{l}\text { Cross-sectional } \\
\text { study }\end{array}$ & Australia & $\begin{array}{l}\mathrm{N}=45 \\
\text { patients }\end{array}$ & $\begin{array}{l}\text { Patient self-reported medication non- } \\
\text { adherence } \\
\text { Suboptimal Inhaler technique } \\
\text { Lack of self-management of exacerbations } \\
\text { plan or teaching by clinicians } \\
\text { Long-term steroid and prophylactic } \\
\text { antibiotic prescription. } \\
\text { Over-prescription of ICS and under } \\
\text { prescription of tiotropium }\end{array}$ & $\begin{array}{l}\text { Appropriating grading of severity of } \\
C^{2} P^{\mathrm{a}} \text { and use of spirometry to } \\
\text { distinguish COPD from other } \\
\text { respiratory conditions like Asthma }\end{array}$ \\
\hline $\begin{array}{l}\text { 27) Fanning } \\
2014^{48}\end{array}$ & $\begin{array}{l}\text { Adherence to guideline-based } \\
\text { antibiotic treatment for acute } \\
\text { exacerbations of chronic } \\
\text { obstructive pulmonary disease } \\
\text { in an } \\
\text { Australian tertiary hospital }\end{array}$ & $\begin{array}{l}\text { This study aimed to (I) define antibiotic } \\
\text { prescribing practice in patients admitted } \\
\text { to a tertiary hospital with } A E C O P D^{2} \text { and } \\
\text { compare this with current locally and } \\
\text { nationally } \\
\text { recognised antibiotic prescribing } \\
\text { guidelines and (2) correlate variations in } \\
\text { guideline concordant antibiotic } \\
\text { prescribing with mean length of stay } \\
\text { (LOS) and rates of unplanned } \\
\text { readmission to hospital }\end{array}$ & $\begin{array}{l}\text { Retrospective } \\
\text { case series }\end{array}$ & Australia & $\begin{array}{l}\mathrm{N}=84 \\
\text { patients }\end{array}$ & $\begin{array}{l}\text { Guideline discordant antibiotic therapy } \\
\text { leading to increased length of stay }\end{array}$ & $\begin{array}{l}\text { Regular clinical audits } \\
\text { Clinical } \\
\text { pharmacists should question the } \\
\text { indication for IV antibiotics in AECOPD } \\
\text { in association with educational campaigns } \\
\text { that raise guideline awareness } \\
\text { Prescribing restrictions utilising } \\
\text { technology and policies }\end{array}$ \\
\hline
\end{tabular}


Table 2 (Continued).

\begin{tabular}{|c|c|c|c|c|c|c|c|}
\hline $\begin{array}{l}\text { Included } \\
\text { Studies } \\
\text { References }\end{array}$ & Title & Aims & Methods & Country & $\begin{array}{l}\text { Sample } \\
\text { Size }\end{array}$ & Barriers & $\begin{array}{l}\text { Solutions/Research } \\
\text { Recommendations }\end{array}$ \\
\hline 28) Au $2013^{46}$ & $\begin{array}{l}\text { Severity of airflow limitation, } \\
\text { co-morbidities and } \\
\text { management of chronic } \\
\text { obstructive pulmonary } \\
\text { disease patients acutely } \\
\text { admitted to hospital }\end{array}$ & $\begin{array}{l}\text { To assess the disease spectrum, severity } \\
\text { of airflow limitation, } \\
\text { admission pattern, co-morbidities, and } \\
\text { management of patients } \\
\text { admitted for acute exacerbations of } \\
\text { chronic obstructive } \\
\text { pulmonary disease }\end{array}$ & $\begin{array}{l}\text { Retrospective } \\
\text { Case series }\end{array}$ & Hong Kong & $\begin{array}{l}\mathrm{N}=253 \\
\text { patients }\end{array}$ & $\begin{array}{l}\text { A low prescription rate } \\
\text { of long-acting bronchodilators } \\
\text { Low utilisation of } \mathrm{NIV}^{\text {a }}\end{array}$ & $\begin{array}{l}\text { Management by a designated } \\
\text { multidisciplinary team is recommended } \\
\text { COPD patients with hypercapnic } \\
\text { respiratory failure are at risk of mortality, } \\
\text { and if feasible, } \\
\text { should be managed by trained staff in a } \\
\text { dedicated team }\end{array}$ \\
\hline $\begin{array}{l}\text { 29) Markun } \\
2017^{33}\end{array}$ & $\begin{array}{l}\text { Acute exacerbated COPD: } \\
\text { room for } \\
\text { improvement in key elements } \\
\text { of care }\end{array}$ & $\begin{array}{l}\text { Measuring the implementation rates of } \\
\text { acute and post-acute } \\
\text { hospital care interventions for AECOPD }\end{array}$ & $\begin{array}{l}\text { Retrospective } \\
\text { chart review }\end{array}$ & Switzerland & $\begin{array}{l}\mathrm{N}=263 \\
\text { patients }\end{array}$ & $\begin{array}{l}\text { Patient education and self-management } \\
\text { advice was low to } 2 \% \\
\text { Over prescription of antibiotics } \\
\text { Inhaler technique assessment, } \\
\text { influenza vaccination/recommendation } \\
\text { and referral for } \\
\text { pulmonary rehabilitation }\end{array}$ & $\begin{array}{l}\text { Checklists (also called care bundles) are } \\
\text { disease } \\
\text { management aids supporting clinicians to } \\
\text { implement predefined elements of care in } \\
\text { individual patients and improve } \\
\text { important outcomes such as } \\
\text { rehospitalization rates } \\
\text { An automatized } \\
\text { linkage between an electronic in-hospital } \\
\text { AECOPD care } \\
\text { bundle and the discharge letter } \\
\text { generation might efficiently } \\
\text { contribute to communication and } \\
\text { comprehensiveness along } \\
\text { the chain of care }\end{array}$ \\
\hline
\end{tabular}




\begin{tabular}{|c|c|c|c|c|c|c|c|}
\hline $\begin{array}{l}\text { 30) Khialani } \\
2014^{23}\end{array}$ & $\begin{array}{l}\text { Emergency department } \\
\text { management of acute } \\
\text { exacerbations of chronic } \\
\text { obstructive pulmonary disease } \\
\text { and factors associated with } \\
\text { hospitalisation }\end{array}$ & $\begin{array}{l}\text { The aim of this study was to identify } \\
\text { biomarkers associated with } \\
\text { hospitalisation in AECOPD patients and } \\
\text { to determine if the ED } \\
\text { concordant with local COPDement was } \\
\text { guidelines }\end{array}$ & $\begin{array}{l}\text { Retrospective } \\
\text { audit }\end{array}$ & Australia & $\begin{array}{l}\mathrm{N}=122 \\
\text { patients }\end{array}$ & $\begin{array}{l}\text { Spirometry was performed in } 17 \% \text { of } \\
\text { patients and } 28 \% \text { of patients with } \\
\text { hypercapnic respiratory failure received } \\
\text { non-invasive ventilation (NIV). } \\
\text { Poor understanding of the clinical } \\
\text { indications for NIV } \\
\text { Limited experience and/or lack of staff } \\
\text { education }\end{array}$ & $\begin{array}{l}\text { Scope for improvement in performing } \\
\text { spirometry and provision of NIV to } \\
\text { eligible patients. } \\
\text { Educational initiatives including checklists } \\
\text { have been shown to improve adherence } \\
\text { to guidelines in the provision of NIV' for } \\
\text { eligible patients. } \\
\text { Further research required to understand } \\
\text { why NIV provision is low in ED' (both in } \\
\text { Australia and worldwide) and measures } \\
\text { that need to be undertaken to improve } \\
\text { this practice. } \\
\text { An alternative to consider for future } \\
\text { studies will be to obtain an accurate } \\
\text { assessment of smoking history, and to use } \\
\text { this information as a proxy measure of } \\
\text { spirometry since pack-years of smoking is } \\
\text { a surrogate measure of the severity of } \\
\text { COPD }\end{array}$ \\
\hline $\begin{array}{l}\text { 31) Meng } \\
\text { 2018 }\end{array}$ & $\begin{array}{l}\text { The impact of } 2011 \text { and } 2017 \\
\text { Global Initiative for } \\
\text { Chronic Obstructive } \\
\text { Pulmonary Disease (GOLDa) } \\
\text { guidelines on allocation and } \\
\text { pharmacological } \\
\text { management of patients with } \\
\text { COPD }^{\mathrm{a}} \text { in Taiwan: } \\
\text { Taiwan Obstructive Lung } \\
\text { Disease (TOLD) study }\end{array}$ & $\begin{array}{l}\text { Evaluate the evolution of distributions } \\
\text { of patients with COPD according to the } \\
2011 \text { and } 2017 \text { Global Initiative for } \\
\text { Chronic Obstructive } \\
\text { Pulmonary Disease }\left(G O L D^{2}\right) \text { guidelines } \\
\text { and to assess the concordance between } \\
\text { the prescribed } \\
\text { medications and the pharmacological } \\
\text { management recommended by the two } \\
\text { distinct classification systems in Taiwan }\end{array}$ & $\begin{array}{l}\text { Retrospective } \\
\text { audit } \\
\text { observational } \\
\text { multicentre }\end{array}$ & Taiwan & $\begin{array}{l}\mathrm{N}=1053 \\
\text { patients }\end{array}$ & $\begin{array}{l}\text { Overtreatment } \\
\text { was unnecessary inhaled corticosteroids } \\
\text { and the main cause of undertreatment } \\
\text { was a lack of } \\
\text { maintenance long-acting bronchodilators }\end{array}$ & $\begin{array}{l}\text { Physicians should make proper } \\
\text { adjustments } \\
\text { of the prescriptions according to the } \\
\text { updated guidelines to ensure the mostly } \\
\text { appropriate treatment for COPD } \\
\text { patients } \\
\text { Promotion of the guidelines might } \\
\text { increase the treatment } \\
\text { appropriateness and improve the patient } \\
\text { outcomes }\end{array}$ \\
\hline
\end{tabular}

(Continued) 
Table 2 (Continued).

\begin{tabular}{|c|c|c|c|c|c|c|c|}
\hline $\begin{array}{l}\text { Included } \\
\text { Studies } \\
\text { References }\end{array}$ & Title & Aims & Methods & Country & $\begin{array}{l}\text { Sample } \\
\text { Size }\end{array}$ & Barriers & $\begin{array}{l}\text { Solutions/Research } \\
\text { Recommendations }\end{array}$ \\
\hline $\begin{array}{l}\text { 32. Johnson } \\
2013^{31}\end{array}$ & $\begin{array}{l}\text { Audit of acute exacerbations } \\
\text { of chronic obstructive } \\
\text { pulmonary disease at } \\
\text { Waitemata District Health } \\
\text { Board, New Zealand }\end{array}$ & $\begin{array}{l}\text { To examine management and outcome of } \\
\text { patients admitted to Waitemata District } \\
\text { Health Board (WDHB) with acute } \\
\text { exacerbations of chronic obstructive } \\
\text { pulmonary disease (AECOPD) and } \\
\text { determine performance according to } \\
\text { evidence-based guidelines }\end{array}$ & $\begin{array}{l}\text { Retrospective } \\
\text { chart review }\end{array}$ & Australia & $\begin{array}{l}\mathrm{N}=156 \\
\text { patients }\end{array}$ & $\begin{array}{l}\text { Poor utilisation of non-invasive ventilation } \\
\text { (NIV), } \\
\text { limited use of ABG and spirometry, and } \\
\text { referral to pulmonary rehabilitation (PR). } \\
\text { Patients with acute respiratory acidosis } \\
\text { did not receive } \\
\text { NIV } \\
\text { Spirometry non-utilisation } \\
\text { Reasons include patient's acute } \\
\text { respiratory status or lack of knowledge of } \\
\text { availability } \\
\text { Lack of knowledge of availability or focus } \\
\text { being on acute issues PR poor detection } \\
\text { of functional } \\
\text { impairment }\end{array}$ & $\begin{array}{l}\text { Improvements in admission/ } \\
\text { assessment procedures in particular } \\
\mathrm{ABG}^{\mathrm{a}} \text { measurement, use of spirometry } \\
\text { and NIV, } \\
\text { PR referral, systemic corticosteroid/NRT } \\
\text { prescription, judicious antibiotic use, and } \\
\text { documentation of performance status. } \\
\text { Educational sessions have been held for } \\
\text { medical staff to raise awareness of the } \\
\text { findings }\end{array}$ \\
\hline $\begin{array}{l}\text { 33. Considine } \\
2011^{66}\end{array}$ & $\begin{array}{l}\text { Emergency department } \\
\text { management of exacerbation } \\
\text { of chronic } \\
\text { obstructive pulmonary disease: } \\
\text { audit of compliance with } \\
\text { evidence-based guidelines }\end{array}$ & $\begin{array}{l}\text { The aim of this study was to examine } \\
\text { compliance with high level evidence for } \\
\text { management of exacerbation of COPD } \\
\text { during the first } 4 \mathrm{~h} \text { of ED care }\end{array}$ & $\begin{array}{l}\text { Retrospective } \\
\text { audit }\end{array}$ & Australia & $\begin{array}{l}\mathrm{N}=273 \\
\text { patients }\end{array}$ & $\begin{array}{l}\text { Only } 56.6 \% \text { of patients in } \\
\text { this study received a systemic steroid } \\
\text { through either oral } \\
\text { or intravenous route } \\
\text { Several patients did not } \\
\text { receive NIV' despite clearly meeting the } \\
\text { criteria of acidosis and/or hypercapnia } \\
\text { Poor uptake of evidence by } \\
\text { clinicians }\end{array}$ & $\begin{array}{l}\text { Compliance with treatment } \\
\text { recommendations may be improved if } \\
\text { guidelines were more specifically targeted } \\
\text { to the process of emergency care rather } \\
\text { than } \\
\text { detailing specific elements of treatment } \\
\text { Further research is warranted to } \\
\text { understand better the barriers to } \\
\text { implementing evidence-based emergency } \\
\text { care for exacerbation of COPD and } \\
\text { inform local guidelines, care processes } \\
\text { and education } \\
\text { programmes. }\end{array}$ \\
\hline
\end{tabular}




\begin{tabular}{|c|c|c|c|c|c|c|c|}
\hline $\begin{array}{l}\text { 34. Alsubaei } \\
\text { 2017 } 17^{39}\end{array}$ & $\begin{array}{l}\text { COPD care in Saudi Arabia: } \\
\text { physicians' awareness and } \\
\text { knowledge of guidelines and } \\
\text { barriers to implementation }\end{array}$ & $\begin{array}{l}\text { To assess Saudi physicians' awareness and } \\
\text { knowledge about chronic obstructive } \\
\text { pulmonary disease } \\
\text { (COPD') guideline recommendations }\end{array}$ & $\begin{array}{l}\text { Cross-sectional } \\
\text { study }\end{array}$ & Saudi Arabia & $\begin{array}{l}\mathrm{N}=44 \\
\text { physicians }\end{array}$ & $\begin{array}{l}\text { Awareness of and adherence to COPD } \\
\text { guidelines } \\
\text { showed that most physicians were not } \\
\text { aware of (61.4\%) and did not adhere to } \\
(63.6 \%) \text { any } \\
\text { of the COPD guidelines in their practice. } \\
\text { Lack of educational material/support' } \\
\text { (72.7\% of } \\
\text { physicians), followed by 'lack of } \\
\text { awareness' } \\
(70.5 \%) \\
\text { Low levels of confidence in } \\
\text { implementing the GOLD } \\
\text { recommendations in them } \\
\text { practice }\end{array}$ & $\begin{array}{l}\text { To develop education and other } \\
\text { interventions such as system support } \\
\text { aiming to improve } \\
\text { physicians' knowledge of COPD to } \\
\text { enhance self-learning among physicians } \\
\text { and increase their level of } \\
\text { confidence to apply COPD guidelines }\end{array}$ \\
\hline $\begin{array}{l}35 \text { Sonstein } \\
2014^{45}\end{array}$ & $\begin{array}{l}\text { Improving Adherence for } \\
\text { Management of Acute } \\
\text { Exacerbation of Chronic } \\
\text { Obstructive Pulmonary } \\
\text { Disease }\end{array}$ & $\begin{array}{l}\text { To assess evidence-based electronic } \\
\text { order sets improve compliance with } \\
\text { clinical practice guidelines }\end{array}$ & $\begin{array}{l}\text { Pre and post } \\
\text { intervention } \\
\text { study (Cohort } \\
\text { study) }\end{array}$ & United States & $\begin{array}{l}\mathrm{N}=420 \\
\text { patients }\end{array}$ & $\begin{array}{l}\text { Only a one third of the patients } \\
\text { hospitalized } \\
\text { with acute exacerbation of chronic } \\
\text { obstructive pulmonary disease (COPD) } \\
\text { received ideal care }\end{array}$ & $\begin{array}{l}\text { Health information technology offers a } \\
\text { unique opportunity to improve } \\
\text { compliance with evidence-based medicine } \\
\text { Implementation of clinical practice } \\
\text { guidelines into the electronic health } \\
\text { record reduced variation in care and } \\
\text { corticosteroid use by 50\% }\end{array}$ \\
\hline
\end{tabular}

(Continued) 
Table 2 (Continued).

\begin{tabular}{|c|c|c|c|c|c|c|c|}
\hline $\begin{array}{l}\text { Included } \\
\text { Studies } \\
\text { References }\end{array}$ & Title & Aims & Methods & Country & $\begin{array}{l}\text { Sample } \\
\text { Size }\end{array}$ & Barriers & $\begin{array}{l}\text { Solutions/Research } \\
\text { Recommendations }\end{array}$ \\
\hline $\begin{array}{l}\text { 36. Cousins } \\
2016^{35}\end{array}$ & $\begin{array}{l}\text { Acute oxygen therapy: a } \\
\text { review of prescribing and } \\
\text { delivery practices }\end{array}$ & $\begin{array}{l}\text { Identify strategies that } \\
\text { have shown promise in facilitating changes } \\
\text { to oxygen prescription and delivery } \\
\text { practice }\end{array}$ & Review & Australia & $\begin{array}{l}\mathrm{N}=17 \\
\text { studies }\end{array}$ & $\begin{array}{l}\text { Insufficient training and education for } \\
\text { medical and nursing staff } \\
\text { Lack of familiarity with oxygen delivery } \\
\text { devices } \\
\text { Lack of understanding of the effects, role } \\
\text { and dangers } \\
\text { of oxygen therapy } \\
\text { Staff time constraints } \\
\text { Necessity to maintain } \mathrm{SpO}_{2}-94 \% \text { due to } \\
\text { the "between } \\
\text { the flags" track and trigger observations } \\
\text { charts } \\
\text { Practical issues related to space and place } \\
\text { for prescribing } \\
\text { oxygen } \\
\text { Difficulties with changing long established } \\
\text { behavior } \\
\text { Patients transferred from other wards/ } \\
\text { departments with } \\
\text { oxygen therapy } \\
\text { Lack of enthusiasm by senior clinical staff } \\
\text { Communication difficulties between } \\
\text { doctors and nurses } \\
\text { Lack of full-time staff or staff turnover }\end{array}$ & $\begin{array}{l}\text { Introduction of oxygen alert stickers } \\
\text { Dedicated oxygen order chart } \\
\text { Clearly delineated section on the drug } \\
\text { chart or changes } \\
\text { to the drug chart to include space for the } \\
\text { transcription of oxygen orders } \\
\text { Informational posters } \\
\text { Email notification/dissemination of } \\
\text { information } \\
\text { Educational session across various clinical } \\
\text { specialities and at various key times } \\
\text { Nurse facilitated reminder system } \\
\text { Development of hospital guidelines/policy } \\
\text { to guide } \\
\text { Practice } \\
\text { Admission bundle with electronic } \\
\text { prescribing system } \\
\text { Message alerts on computer login screens }\end{array}$ \\
\hline
\end{tabular}




\begin{tabular}{|c|c|c|c|c|c|c|c|}
\hline $\begin{array}{l}\text { 37. Cousins } \\
2020^{21}\end{array}$ & $\begin{array}{l}\text { Management of acute COPD } \\
\text { exacerbations in Australia: do } \\
\text { we follow the guidelines }\end{array}$ & $\begin{array}{l}\text { To assess adherence to the Australian } \\
\text { national guideline (COPD-X) against } \\
\text { audited practice, and to document the } \\
\text { outcomes of patients hospitalised with an } \\
\text { acute exacerbation of chronic obstructive } \\
\text { pulmonary disease (COPD) at discharge } \\
\text { and } 28 \text { days after }\end{array}$ & $\begin{array}{l}\text { Retrospective } \\
\text { case audit }\end{array}$ & Australia & $\begin{array}{l}\mathrm{N}=171 \\
\text { patients }\end{array}$ & $\begin{array}{l}\text { Spirometry was performed in only 22.7\% } \\
\text { of admissions } \\
\text { Patients with no change in the sputum } \\
\text { color (85.7\%) or volume (84.9\%) were } \\
\text { also prescribed antibiotics } \\
\text { Reasons for not using non-invasive } \\
\text { ventilation (NIV) or invasive ventilation } \\
\text { included a documented decision not to } \\
\text { escalate to NIV or invasive ventilation } \\
(18.2 \%) \text {, "patient responded to medical } \\
\text { therapy" (45.6\%) and in 36.4\%, no reason } \\
\text { was listed } \\
\text { Referral to pulmonary rehabilitation was } \\
\text { low in most centers (mean 32.4\%) } \\
\text { Lack of spirometry performed during the } \\
\text { admission increased the odds of 28-day } \\
\text { readmission } \\
\text { COPD-X argues that "even the sickest of } \\
\text { patients can perform an FEVI } \\
\text { manoeuvre" the GOLD guidelines do not } \\
\text { routinely recommend that sick patients } \\
\text { perform spirometry. It is also important } \\
\text { to consider the practicality or capacity of } \\
\text { emergency department staff to obtain } \\
\text { acceptable spirometry traces } \\
\text { NII" is underutilised. } \\
\text { Referral to pulmonary rehabilitation } \\
\text { programs is very low }\end{array}$ & Clinical Care Bundles \\
\hline
\end{tabular}

Abbreviations: ${ }^{2} C O P D$, chronic obstructive pulmonary disease; ACP, advanced care planning; N, number of; UK, United Kingdom; GOLD, Global Initiative Obstructive Lung Disease; IV, intravenous; RF, respiratory failure; RCNS, respiratory nurse specialist; AUDIPOC, AECOPD (acute exacerbation of COPD); NIV, non-invasive ventilation; ABG, arterial blood gas; GMP, general medicine practitioners; RS, respiratory specialist; SABA, short-acting beta-agonists; LABA, long-acting beta agonist bronchodilators; ICS, inhaled corticosteroids; CP, care pathway; VBG, venous blood gas; FEVI, forced expiratory volume; CME, continuing medical education; LOS, length of stay; PR, pulmonary rehabilitation; NRT, nicotine replacement therapy. 
respiratory ward-based COPD clinical pathways and atomistic acute ED clinical pathways generally due to the difference in care focus, time constraints, national targets, and lack of human and fiscal resources such as beds, clinicians, staff, and high patient turnover (environmental context and resources). ${ }^{11,15,23,40}$ Targeted speciality care order sets specifically designed for departmental needs and care focus such as in the ED is highly recommended for implementation. ${ }^{11,15,41}$

\section{Pharmacological Management}

Guidelines suggest accurate pharmacological therapy will optimise function, prevent deterioration, prevent exacerbations and sustain pulmonary function. ${ }^{8}$ Misalignment of prescribing with GOLD recommendations between respiratory physicians and general physicians was identified as being due to a lack of interspeciality communication and guidance amongst clinicians. This was one of the major barriers reported with COPD pharmacological management (social/professional role and identity). ${ }^{36}$

\section{Corticosteroids Guidelines Non- adherence and Potential Solutions}

Multiple studies have reported on variability in duration, dosing and inconsistency from guidelines with corticosteroids management (behavioural regulation). ${ }^{10,11,18,30,37,38,42,43}$ Systemic corticosteroid regimens used in clinical practice are administered for much longer periods and at higher doses than recommended in guidelines (knowledge). ${ }^{10,11,17,25,31-34}$ Steroid doses relevant to an asthma diagnosis and treatment are utilised to treat for COPD (knowledge). ${ }^{37}$ Despite the evidence, oral steroids are not inferior to intravenous steroids, with dose duration tripled from the recommended 5 days in practice (knowledge). ${ }^{44}$ Use of steroids without indication or overtreatment with ICS inhalers have been reported from multiple studies leading to longer hospital length of stay and mortality. ${ }^{10,30,37,42}$ Approximately half of the COPD readmissions in an inpatient urban teaching hospital study in the United States did not receive steroids during their first admission. ${ }^{18}$ Lack of awareness and knowledge of guidelines were reported to be a firm barrier to steroid prescription nonadherence (knowledge). $9,10,38,42,44$ Interactive educational tools and clinical champions have appeared to provide an increase in pharmacological adherence by increasing awareness of the guidelines. ${ }^{38,45}$

\section{Bronchodilators and Antibiotics Guidelines Non-adherence and Potential Solutions}

Two studies, one Australian and one from Hong Kong, reported differences in prescription of long-acting bronchodilators (LABA) between general physicians and respiratory physicians despite guideline instructions (Social/professional role and identity). ${ }^{36,46}$ Inappropriate prophylactic antibiotic prescription despite normal white cell count is a concern with antimicrobial resistance an issue worldwide (Knowledge, behavioural regulation). ${ }^{10,22,33,38,43,47}$ Dual antibiotic therapy choice discordant from current guidelines was observed in $90 \%$ of patients in another Australian study. ${ }^{48}$ Discordant duration of antibiotic therapy and failure to switch to oral antibiotics have been linked with an increased length of hospital stay (Knowledge). ${ }^{48}$ The availability of a wide range of inhaler devices, coupled with a lack of patient education and checking of inhaler technique was noted as a major barrier potentially contributing to COPD exacerbations (Knowledge and skills). ${ }^{15,49}$ Lack of knowledge of updated guidelines and memory, attention or decision processes merged with environmental barriers such as low staffing, and time constraints contributed hugely to inaccurate pharmacological management. Dedicated AECOPD pathways may improve antibiotic or other drug selection and help to uplift pharmacological concordance with guidelines. ${ }^{47}$ Easier to use devices and educational strategies on proper inhaler use from health caregivers can reduce readmissions. ${ }^{42}$

\section{Barriers and Potential Solutions for Increasing Pharmacological Guidelines Adherence}

Respiratory specialists and nurses adhered to pharmacological guidelines more accurately over internists (Social/professional role and identity). ${ }^{36,50}$ Cross fertilization of knowledge across departments and interdisciplinary clinicians assists with consistently delivering pharmacological management to provide evidence-based care in the most efficient manner. ${ }^{36}$ The development and validation of appropriate educational tools for inhaler techniques is necessary to assist clinicians and other health-care professionals who are involved in selecting inhalation devices. ${ }^{14,38}$ Given the wide range of inhaler devices available, inhaler prescription, technique and adherence are not checked or educated on well by interdisciplinary staff (Behavioural regulation). ${ }^{32,34,36,38,42}$ Dedicated and holistic bundles of care for AECOPD have been implemented in the United Kingdom and have been 
demonstrated to improve patient management. ${ }^{24}$ Training, modeling and enablement utilising education and other interventions to enhance self-learning among physicians was recommended and included strategies such as informational posters, and hospital guidelines with updated evidence. Educating clinicians regarding the indications and contraindication for corticosteroids and antibiotics including encouragement to prescribe according to the guidelines or standardizing prescriptions utilising electronic formats is a potential solution recommended by multiple studies. ${ }^{10,12,41}$ Ambiguity, disagreement or when individual clinicians see the guideline as an interference in her/his freedom of clinical judgement is reported as a barrier (Social/professional role and identity). ${ }^{38}$ Motivation with education, incentivisation post guideline adherence audits and environmental enablement utilising point of care resources may mitigate this phenomenon. ${ }^{25}$ Change champions and senior leadership to discuss and influence total staff behaviour is reported to have assisted with this barrier in some implementation studies. ${ }^{51}$

\section{Non-Pharmacological Management}

Non-pharmacological management includes pulmonary rehabilitation, smoking cessation, immunisations, selfmanagement plans, COPD action plans, palliative care, and mental health assessment. GOLD and COPD-X guidelines recommend all patients with COPD after an acute exacerbation should have a referral for pulmonary rehabilitation within 2-3 weeks. ${ }^{8}$ Major barriers were identified that included suboptimal understanding of COPD nonpharmacological recommendations, lack of perceived treatment benefit, along with ambiguity on self-efficacy and time constraints (knowledge, environmental and context resources). ${ }^{19,27,33,36}$

\section{Pulmonary Rehabilitation Barriers and Potential Solutions}

In studies surrounding guidelines adherence evidence shows very low pulmonary rehabilitation referrals after a COPD exacerbation (Behavioural regulation). ${ }^{10,11,20,31,33,42}$ Referral rates to pulmonary rehabilitation have reportedly increased from $13.6 \%$ to $68 \%$ with implementation of a COPD care bundle reported from a pre- and post-intervention study conducted in one Ireland inpatient unit. ${ }^{20}$ Lack of knowledge of benefits, updated knowledge (in reference to publishing years), knowledge of existing community resources, and lack of patient education regarding attendance of these programs were identified as major barriers
(Knowledge). These knowledge deficits are identified as particular barriers for non-respiratory physicians (Knowledge). ${ }^{20,38,52}$ Some other barriers include lower support for rehabilitation at multiple levels such as time constraints, difficult referral process, lack of staffing resources, infrastructure, and lack of clarity on who provides the referral (Environmental and Context resources, Social/professional role identity). ${ }^{25,36}$ Well-structured screening protocols or program-based multimodality COPD care services are highly recommended for development to address identified barriers. $^{12}$ Political commitment, sustained funding, and establishment of a pulmonary rehabilitation unit were found to be of the utmost importance for Nigerian and possibly other developing COPD populations. ${ }^{2,29}$ Recommendations of referral to rehabilitation professionals included making lengthier commitments to rehabilitation, facilitating more activity by motivating and encouraging patients with COPD, and reducing their fears and reinforcing the benefits of lifelong activity. ${ }^{20,52}$

\section{Smoking Cessation, Inhaler Technique, Immunisation and Vaccination Guidelines Non-adherence and Potential Solutions}

Smoking cessation and immunisation are highly recommended and significant in preventing COPD exacerbation and preserving lung function. A general staff perception acting as a barrier concluded these to be the responsibility of the primary care physician, hence a lack of addressing this problem during an acute admission is reported in two studies (Social/professional role and identity). ${ }^{20,52}$ Lack of prevention of future exacerbations with particular attention to smoking cessation, immunisation, knowledge of current therapy including inhaler technique and self-management is reportedly low (Knowledge). ${ }^{29,33,34,52}$ Minimal support is provided to implement smoking cessation in public hospitals with human resources, staffing, smoking cessation teams/champions, telephone support, and a lack of role clarity in terms of initiating the cessation education (Environmental and Context resources, Social/ professional role identity). ${ }^{10,29,34,52}$ In Ireland implementation of a care bundle and care pathway improved referral for smoking cessation assistance from $18.2 \%$ to $100 \%$ and significantly lowered the 30 -day readmission rates. ${ }^{20,34,53}$ Care bundle implementation strategies may be adopted by national and international health systems to improve smoking cessation. Multifaceted implementation programs 
including patient pamphlets, brochures, electronic learning modules, and electronic reminders at point of clinical practice have proven successful. ${ }^{12}$ Vaccination provision records are lower in summer months compared with winter admissions and unvaccinated patients were not vaccinated in the acute setting. ${ }^{18}$ Time- and resource-poor clinicians often overlook vaccination as a primary care physician responsibility and trust this will be completed in the community setting (Social/professional role and identity, Environmental and Context resources). ${ }^{10,20,33,54,55}$ Affordability of vaccines in developing countries was identified as a barrier (Environmental and Context resources). ${ }^{29}$

Enablers identified were that physicians should collaborate with hospital authorities to establish smoking cessation teams, vaccination change champions and pulmonary rehabilitation units. ${ }^{56}$ Difficulty remembering the most up to date guidelines or recalling all delivery devices and management modality from COPD guidelines (Memory attention and decision-making process) was problematic and presented as a barrier. ${ }^{12,41,57}$ Environmental restructuring, enablement, and education initiated with Point of Care checklists in respiratory wards have improved guideline adherence. ${ }^{12,24,41}$ Health professional education, decisionmaking algorithms (including electronic systems), reminders at the time of consultation, and continuous quality assurance programs with admission/ discharge bundles using electronic prescribing systems are recommended strategies to add consistency and reduce error or nonconformance. $^{12,18,24,58}$

\section{Anxiety/ Depression Screening and Palliative Care Guidelines Non-adherence and Potential Solutions}

Barriers in screening and pharmacological treatment for clinically confirmed depression were documented as not being part of routine care, albeit this was not measured by many studies that reported on non-adherence of COPD clinical guidelines (Behavioral regulation). ${ }^{41}$ The prevalence of clinical depression in patients with COPD varies from $18 \%$ to $80 \%$, yet this aspect is not screened regularly with AECOPD. ${ }^{59}$ Palliative care and care planning in advanced COPD remain discordant largely due to difficulty in prognosis of the disease due to variable disease trajectories (Behavioral regulation, Social/professional role and identity). ${ }^{60}$ Care is reported to be fragmented, episodic and reactive and the role of carers were poorly recognised in end stage COPD (Knowledge and Behavioral regulation). ${ }^{61,62}$ Respiratory doctors initiating palliative care conversations, and with subsequent referral to palliative care clinicians and integrating multidisciplinary services could address fragmented care, however more work is required in this space (Social/professional role and identity). ${ }^{62}$ Clinicians lacking time, fearful of taking away patient hope, lack of palliative specialist availability, insufficient communication and collaboration, poor access and lack of service availability are major barriers to COPD adherence (Environmental and context resources). ${ }^{60,62-65} \mathrm{COPD}$ action plans reduce hospitalisations and are recommended as part of COPD selfmanagement plans. ${ }^{8}$ Patients often receive minimal to no education on acute discharge from inpatient units. More work is required in this space (Knowledge and Behavioural regulation). ${ }^{66}$ Recommendations that require patient education and team collaboration are the ones particularly discordant with current guidelines (Knowledge). ${ }^{33,34,49}$ Lack of mental health assessments and palliative care significant and clinically appropriate awareness strategies aligned with poorly controlled COPD patient outcomes presented as major barriers (Social/professional role and identity, Behavioral regulation).

\section{Potential Solutions to Improve Guidelines Adherence with Non-Pharmacological Management}

Targeted health professional education, electronic checklists, user friendly and easy access resources, improvised communication between primary care physicians, educational campaigns, hospital staff audit and educational sessions presented in many studies were specifically related to improving concordance in health-care settings. ${ }^{11,12,23,32-34,38,47-49,52,54,58,66}$ Care bundles have resulted in reduced readmissions for COPD and increased adherence to guidelines by improving referrals for inhaler technique (59.1\% to $91.2 \%$ ) and smoking cessation ( $13.6 \%$ to $68 \%) .{ }^{20}$ Referral rates to pulmonary rehabilitation rose higher and similar improvements were seen in the administration of self-management plans. ${ }^{20}$ Communication between Guideline Committees and Clinicians should be improved and variability in resources and organisation of hospitals, patient characteristics, process of care, and outcomes needs to be addressed. ${ }^{54}$ 


\section{Discussion}

Multidimensional barriers have evidently contributed to global COPD guideline non-concordance. Research repetitively reports a lack of awareness, knowledge and skills being the significant challenges demonstrating guidelines are not well disseminated or implemented in clinical practice. Major barriers are reported as a lack of awareness, lack of considering the complexity of the guideline, high turnover of patients and the involvement of inter disciplines. Mitigating strategies include providing guideline resources at point of care electronically. Diagnostic and pharmacological management are mostly well adhered to compared to non-pharmacological management (self-management education, COPD action plans, smoking cessation, pulmonary rehabilitation, palliative care, inhaler adherence and technique, home oxygen, immunisation). Non-pharmacological management seeks to provide better implementation strategies to enhance guideline concordance. Strategic implementation for interdisciplinary communication and cross fertilisation of knowledge is recommended by researchers for decades and yet globally literature is still reporting non-adherence. This review provides the inclusion of multifaceted implementation strategies for targeted implementation of COPD guidelines for national and international clinical settings compiled from research evidence and utilising the TDF implementation framework. Motivation using environmental restructuring, increasing education, and disseminating guidelines in the working area or utilising suitable implementation strategies is highly associated with improving guideline adherence rates.

This study collated all barriers and probable solutions, and recommends multiple strategies that may be adopted by stakeholders with suitability to local or national needs (see Table 3). A significant recommendation from this study arising from frequency scores and the implementation framework is to install the proforma ideally in an electronic format in acute care settings from hospital (triage to discharge) to primary care. Concurrent studies and reviews have similar findings and recommend electronic or pre-formatted order sets to improve guideline adherence in Australia. ${ }^{10-12,18,20,33,47,54}$ This implementation strategy appears to be capable of addressing almost all barriers (see Table 3). The electronic proforma will provide easy access, increase knowledge and awareness, provide role clarity, time efficiency, and provide all resources in one place with self-learning resources. Other advantages include consistent pharmacological and non-pharmacological standardisation of management, provision of patient information or self-management resources, electronic referrals, data for future research, practicability, interdisciplinary acceptability, easier access to community services, automation of processes, discharge planning with primary care, and clinical behavior regulation. Future potential of such digital proforma with access to primary care records with read and write access will alleviate communication issues between primary care and speciality clinicians. Potential digital proforma can target fragmented care elements to initiate a new implementation strategy, with the capacity to liaise with a community pharmacist, nurses and other interdisciplinary staff from the hospital to reduce or avoid long hospital stays. Educating and self-learning opportunity is available with this strategy of implementation in the case of an interdisciplinary clinician requiring education resources to be provided to patients or staff. Proforma aided COPD management in concordance to guidelines significantly improved the standards of care in COPD patients especially among junior doctors. ${ }^{57} \mathrm{ED}$ short stay unit pathways and access to community follow-up care with primary care or specialist clinics, and disease-specific outreach services is recommended. ${ }^{17}$ Guidelines specifically targeted to the process of emergency care may be more meaningful to ED clinicians, however further research is warranted to understand best implementation strategies for the Emergency department. ${ }^{11,67}$

\section{Strengths and Limitations}

This mixed method systematic review explored both qualitative and quantitative studies to deeply comprehend barriers to interdisciplinary staff guideline adherence. The Theoretical Domains Framework (TDF) utilisation facilitates understanding of existing barriers and probable clinical behaviour change solutions to improve concordance. Interdisciplinary perspectives to improve collaboration and concordance may lead to multifaceted implementation strategies. Due to the wide gap and the different focus of studies only three domains were identified from the TDF. Paucity of existing good quality data and reporting may confine our ability to report true barriers of concordance.

\section{Conclusion}

Barriers and potential solutions were identified for most clinical recommendations from the guidelines. The 
Table 3 Summary Table on Electronic Proforma's Ability to Address the Identified Barriers

\begin{tabular}{|c|c|}
\hline Summary of Barriers & E-ICP Capability to Address the Barriers \\
\hline $\begin{array}{l}\text { Lack of knowledge or } \\
\text { awareness }\end{array}$ & $\begin{array}{l}\text { - E-ICP }{ }^{a} \text { will provide } \text { COPD }^{a} \text { guidelines for interdisciplinary staff at point of care } \\
\text { - Self-learning resources }\end{array}$ \\
\hline Lack of skills & $\begin{array}{l}\text { - Integrating latest videos from lung foundation Australia to educate staff on inhaler techniques } \\
\text { - Provision of digital learning resources } \\
\text { - Despite previous qualification and lack of respiratory experience interdisciplinary staff will have access to clinical } \\
\text { guidelines and e-learning resources }\end{array}$ \\
\hline Professional role identity & - Electronic one touch, direct referrals that reaches primary care /inpatient/outpatient facilities from ED ${ }^{\mathrm{a}}$ \\
\hline $\begin{array}{l}\text { Ambiguity in management of } \\
\text { guidelines }\end{array}$ & - Evidence based and speciality based advice can be integrated for reassurance \\
\hline $\begin{array}{l}\text { Poor pharmacological } \\
\text { prescription }\end{array}$ & - Consistent pharmacological prescription with guideline could be utilised through electronic proforma \\
\hline Time constraints & $\begin{array}{l}\text { - Easier outpatient referrals through electronic referrals } \\
\text { - Convenience and easy access encourage interdisciplinary staff }\end{array}$ \\
\hline $\begin{array}{l}\text { Interdisciplinary } \\
\text { communication }\end{array}$ & - Direct and faster inter departmental referrals \\
\hline Smoking cessation & - Smoking cessation patient resources (pamphlet, websites) \\
\hline Pulmonary rehabilitation & - Direct referrals or patient resources to book online \\
\hline Environmental barriers & $\begin{array}{l}\text { - Changing to easier electronic referrals will require lesser staffing resources } \\
\text { - Time efficient and user-friendly } \\
\text { - Addresses difficulty recalling every guideline } \\
\text { - Convenience of implementation using I-EMR }\end{array}$ \\
\hline Fragmented care & $\begin{array}{l}\text { - Most of the care fragmentation occurs during discharge from hospitals to primary care. Direct referrals from } \\
\text { hospitals to primary care community units (pulmonary rehabilitation) will allow clinicians to monitor where the } \\
\text { care falls and target this area for future evaluation and implementation to improve concordance }\end{array}$ \\
\hline
\end{tabular}

Abbreviations: ${ }^{a} E-I C P$, electronic integrated care proforma; COPD, chronic obstructive pulmonary disease; ED, emergency department,; I-EMR, integrated electronic medical records.

utilisation of the TDF implementation framework suggests electronic order sets/ proforma with guideline resources at point of care and easily accessible digital community referrals. This enables targeted recommendations to both pharmacological and non-pharmacological management that reverberates solutions to improve concordance. Various other implementation strategies are also recommended in this study for developing countries where digitalising is not an immediate option. Care bundles and clinical champions have proven to be effective in Europe and Australia. Stakeholders will have the opportunity to compare, analyse and conduct feasibility studies of different approaches recommended in this study that may be suitable for their settings.

\section{Abbreviations}

COPD, chronic obstructive pulmonary disease; TDF, theoretical domains framework; E-ICP, electronic integrated COPD proforma; HRQoL, health-related quality of life; JBI, Joanna Briggs Institute; GOLD, Global Initiative for Obstructive Lung Disease; COPD-X plan, chronic obstructive pulmonary disease-X plan; $\mathrm{ABG}$, arterial blood gas; NIV, non-invasive ventilation; ED, emergency department; LABA, long-acting bronchodilators; AECOPD, acute exacerbation of chronic obstructive pulmonary disease.

\section{Patient and Public Involvement}

No patients from the included studies were involved in this review. 


\section{Ethics and Dissemination}

Ethics approval is not required for this study as all data were obtained from publicly available studies. Knowledge and interpretations from this review will provide recommendations towards prominent implementation strategies to increase COPD guideline concordance. The results of this study will be presented before industry stakeholders, interdisciplinary clinicians, and appropriate future conferences to develop and assist with implementation initiatives.

\section{Acknowledgments}

We acknowledge Professor Sonya Osborne for her valuable input and expertise during University of Southern Queensland writing retreats. We acknowledge expertise of the University of Southern Queensland, Health Sciences Librarian, Rowena McGregor for assistance during the preliminary search phase.

\section{Author Contributions}

All authors made a significant contribution to the work reported, whether that is in the conception, study design, execution, acquisition of data, analysis and interpretation, or in all these areas; took part in drafting, revising or critically reviewing the article; gave final approval of the version to be published; have agreed on the journal to which the article has been submitted; and agree to be accountable for all aspects of the work.

\section{Disclosure}

The authors report no Competing interests related to this work.

\section{References}

1. Quaderi S, Hurst J. The unmet global burden of COPD. Glob Health Epidemiol Genom. 2018;3. doi:10.1017/gheg.2018.1

2. World Health Organisation. WHO global health estimates: the top 10 causes of death; 2020.

3. The Australian Lung Foundation. COPD: the statistics, The Australian Lung Foundation; 2016

4. Australian Institute of Health and Welfare. Chronic obstructive pulmonary disease; 2017. Available from: https:/www.aihw.gov.au/ reports/chronic-respiratory-conditions/copd/contents/treatment-man agement. Accessed December 16, 2021.

5. British Lung Foundation. Deaths from COPD; 2012. Available from: https://statistics.blf.org.uk/copd. Accessed December 16, 2021.

6. May SM, Li JTC. Burden of chronic obstructive pulmonary disease: healthcare costs and beyond. In: Allergy and Asthma Proceedings. OceanSide Publications; 2015.

7. Mathers CD, Loncar D. Projections of global mortality and burden of disease from 2002 to 2030 . World Health Organisation. PLoS Med. 2006;3:209-224.
8. Yang IA, George J, Jenkins S. The COPD-X Plan: Australian and New Zealand Guidelines for the management of chronic obstructive pulmonary disease 2018; 2018.

9. Ruth Hadfield MH. Global strategy for the diagnosis, management, and prevention of chronic obstructive pulmonary disease 2019 report. Ruth Hadfield MH, ed; 2019.

10. Sha J, Worsnop CJ, Leaver BA, et al. Hospitalised exacerbations of chronic obstructive pulmonary disease: adherence to guideline recommendations in an Australian teaching hospital. Intern Med J. 2019;50:453-459.

11. Kelly AM, Van Meer O, Keijzers G, et al. Get with the guidelines management of COPD in EDs in Europe and Australasia is suboptimal. Intern Med J. 2019. doi:10.1111/imj.14323

12. Overington JD, Huang YC, Abramson MJ, et al. Implementing clinical guidelines for chronic obstructive pulmonary disease: barriers and solutions. J Thorac Dis. 2014;6(11):1586-1596. doi:10.3978/j. issn.2072-1439.2014.11.25

13. Kruis AL, Smidt N, Assendelft WJ, et al. Integrated disease management interventions for patients with chronic obstructive pulmonary disease. Cochrane Database Syst Rev. 2013. doi:10.1002/14651858. CD009437.pub2

14. Issac H, Moloney C, Taylor M, et al. Protocol: mapping of modifiable barriers and facilitators with interdisciplinary chronic obstructive pulmonary disease (COPD) guidelines concordance within hospitals to the theoretical domains framework: a mixed methods systematic review protocol. BMJ Open. 2020;10(7):e036060. doi:10.1136/bmjopen-2019-036060

15. Hancy Issac MT, Moloney C, Lea J. Exploring factors contributing to Chronic Obstructive Pulmonary Disease (COPD) guideline nonadherence and potential solutions in the emergency department: interdisciplinary staff perspective. J Multidiscip Healthc. 2021;14:767. doi:10.2147/JMDH.S276702

16. Légaré F, Ratté S, Gravel K, et al. Barriers and facilitators to implementing shared decision-making in clinical practice: update of a systematic review of health professionals' perceptions. Patient Educ Couns. 2008;73(3):526-535. doi:10.1016/j.pec.2008.07.018

17. Francke AL, Smit MC, de Veer AJ, et al. Factors influencing the implementation of clinical guidelines for health care professionals: a systematic meta-review. BMC Med Inform Decis Mak. 2008;8(1):111. doi:10.1186/1472-6947-8-38

18. Lipari M, Smith AL, Kale-Pradhan PB, et al. Adherence to GOLD guidelines in the inpatient COPD population. J Pharm Pract. 2018;31 (1):29-33. doi:10.1177/0897190017696949

19. Menzella F, Facciolongo N, Lusuardi M, et al. Clinical audit on diagnostic accuracy and management of respiratory failure in COPD Respir Care. 2012;57(12):2067-2073. doi:10.4187/respcare.01502

20. Migone C, O'Connor M, Kelly E, et al. Patients hospitalised with an acute exacerbation of COPD: is there a need for a discharge bundle of care? Ir Med J. 2015;108(9):273-275.

21. Cousins JL, Wood-Baker R, Wark PAB, et al. Management of acute COPD exacerbations in Australia: do we follow the guidelines? ERJ Open Res. 2020;6(2):00270-2019. doi:10.1183/23120541.00270-2019

22. Roberts CM, Lopez-Campos JL, Pozo-Rodriguez F, et al. European hospital adherence to GOLD recommendations for chronic obstructive pulmonary disease (COPD) exacerbation admissions. Thorax. 2013;68(12):1169-1171. doi:10.1136/thoraxjnl-2013-203465

23. Khialani B, Sivakumaran P, Keijzers G, et al. Emergency department management of acute exacerbations of chronic obstructive pulmonary disease and factors associated with hospitalization. J Res Med Sci. 2014;19(4):297-303.

24. McCarthy C, Brennan J, Brown L, et al. Use of a care bundle in the emergency department for acute exacerbations of chronic obstructive pulmonary disease: a feasibility study. Int J Chron Obstruct Pulmon Dis. 2013;8:605. doi:10.2147/COPD.S52883 
25. Michie S, Atkins L, West R. The Behaviour Change Wheel. A Guide to Designing Interventions. 1st ed. Great Britain: Silverback Publishing; 2014:1003-1010.

26. Atkins L, Francis J, Islam R, et al. A guide to using the Theoretical Domains Framework of behaviour change to investigate implementation problems. Implement Sci. 2017;12(1):1-18. doi:10.1186/s13012017-0605-9

27. Michie S, Richardson M, Johnston M, et al. The behavior change technique taxonomy (v1) of 93 hierarchically clustered techniques: building an international consensus for the reporting of behavior change interventions. Ann Behav Med. 2013;46(1):81-95. doi:10.1007/s12160-013-9486-6

28. Stern C, Lizarondo L, Carrier J, et al. Methodological guidance for the conduct of mixed methods systematic reviews. JBI Evid Synth. 2020;18(10):2108-2118. doi:10.11124/JBISRIR-D-19-00169

29. Desalu OO, Onyedum CC, Adeoti AO, et al. Guideline-based COPD management in a resource-limited setting - physicians' understanding, adherence and barriers: a cross-sectional survey of internal and family medicine hospital-based physicians in Nigeria. Prim Care Res J. 2013;22(1):79-85. doi:10.4104/pcrj.2013.00014

30. Kim T-O, Shin H-J, Kim Y-I, et al. Adherence to the GOLD guideline in COPD management of South Korea: findings from KOCOSS study 2011-2018. Chonnam Med J. 2019;55(1):47-53. doi:10.4068/ cmj.2019.55.1.47

31. Johnson C, Connolly MJ, Clover S, et al. Audit of acute exacerbations of chronic obstructive pulmonary disease at Waitemata District Health Board, New Zealand. New Zealand Med J. 2013;126 (1378):15-25.

32. Susanto C, Thomas PS. Assessing the use of initial oxygen therapy in chronic obstructive pulmonary disease patients: a retrospective audit of pre-hospital and hospital emergency management. Intern Med J. 2015;45(5):510-516. doi:10.1111/imj.12727

33. Markun S, Franzen DP, Dalla Lana K, et al. Acute exacerbated COPD: room for improvement in key elements of care. Int $J$ Chron Obstruct Pulmon Dis. 2017;12:2969. doi:10.2147/COPD.S145496

34. Vanhaecht K, Lodewijckx C, Sermeus W, et al. Impact of a care pathway for COPD on adherence to guidelines and hospital readmission: a cluster randomized trial. Int J Chron Obstruct Pulmon Dis. 2016;11:2897. doi:10.2147/COPD.S119849

35. Cousins JL, Wark PA, McDonald VM. Acute oxygen therapy: a review of prescribing and delivery practices. Int J Chron Obstruct Pulmon Dis. 2016;11:1067. doi:10.2147/COPD.S103607

36. Wijayaratne K, Sivakumaran P, Wijayaratne K, et al. Differences in care between general medicine and respiratory specialists in the management of patients hospitalized for acute exacerbations of chronic obstructive pulmonary disease. Ann Thorac Med. 2013;8 (4):197-203. doi:10.4103/1817-1737.118499

37. Harrison A, Borg B, Thompson B, et al. Inappropriate inhaled corticosteroid prescribing in chronic obstructive pulmonary disease patients. Intern Med J. 2017;47(11):1310-1313. doi:10.1111/imj.13611

38. Tang CY, Taylor NF, McDonald CF, et al. Level of adherence to the GOLD strategy document for management of patients admitted to hospital with an acute exacerbation of COPD. Respirology. 2014;19 (8):1191-1197. doi:10.1111/resp.12361

39. Alsubaiei M, Frith PA, Cafarella PA, et al. COPD care in Saudi Arabia: physicians' awareness and knowledge of guidelines and barriers to implementation. Int $J$ Tuberc Respir Dis. 2017;21 (5):592-595. doi:10.5588/ijtld.16.0656

40. Sneath E, Bunting D, Hazell W, et al. Pre-hospital and emergency department pathways of care for exacerbations of chronic obstructive pulmonary disease (COPD). J Thorac Dis. 2019;11(Suppl 17):S2221. doi: $10.21037 /$ jtd.2019.10.37

41. Gerber A, Moynihan C, Klim S, et al. Compliance with a COPD bundle of care in an Australian emergency department: a cohort study. Clin Respir J. 2018;12(2):706-711. doi:10.1111/crj.12583
42. Hsieh M-J, Huang S-Y, Yang T-M, et al. The impact of 2011 and 2017 Global Initiative for Chronic Obstructive Pulmonary Disease (GOLD) guidelines on allocation and pharmacological management of patients with COPD in Taiwan: Taiwan Obstructive Lung Disease (TOLD) study. Int J Chron Obstruct Pulmon Dis. 2018;13:2949. doi:10.2147/COPD.S176065

43. Ta M, George J. Management of chronic obstructive pulmonary disease in Australia after the publication of national guidelines. Intern Med J. 2011;41(3):263-270. doi:10.1111/j.14455994.2009.02133.x

44. Marcos PJ, Nieto-Codesido I, de Jorge Dominguez-Pazos S, et al. Treatment with systemic steroids in severe chronic obstructive pulmonary disease exacerbations: use of short regimens in routine clinical practice and their impact on hospital stay. Archivos de Bronconeumología. 2017;53(11):611-615. doi:10.1016/j. arbr.2017.09.007

45. Sonstein L, Clark C, Seidensticker S, et al. Improving adherence for management of acute exacerbation of chronic obstructive pulmonary disease. Am J Med. 2014;127(11):1097-1104. doi:10.1016/j. amjmed.2014.05.033

46. Au LH, Chan HS. Severity of airflow limitation, co-morbidities and management of chronic obstructive pulmonary disease patients acutely admitted to hospital. Hong Kong Med J. 2013;19(6):498503. doi:10.12809/hkmj133909

47. Brownridge D, Zaidi S. Retrospective audit of antimicrobial prescribing practices for acute exacerbations of chronic obstructive pulmonary diseases in a large regional hospital. J Clin Pharm Ther. 2017;42 (3):301-305. doi:10.1111/jept.12514

48. Fanning M, McKean M, Seymour K, et al. Adherence to guidelinebased antibiotic treatment for acute exacerbations of chronic obstructive pulmonary disease in an Australian tertiary hospital. Intern Med J. 2014;44(9):903-910. doi:10.1111/imj.12516

49. Melani AS, Paleari D. Maintaining control of chronic obstructive airway disease: adherence to inhaled therapy and risks and benefits of switching devices. COPD. 2016;13(2):241-250. doi:10.3109/ 15412555.2015.1045972

50. Sandhu SK, Chu J, Yurkovich M, et al. Variations in the management of acute exacerbations of chronic obstructive pulmonary disease. Can Respir J. 2013;20(3):175-179. doi:10.1155/2013/501038

51. Goedken CC, Livorsi DJ, Sauder M, et al. "The role as a champion is to not only monitor but to speak out and to educate": the contradictory roles of hand hygiene champions. Implement Sci. 2019;14 (1):1-11. doi:10.1186/s13012-019-0943-x

52. Pretto JJ, McDonald VM, Wark PAB, et al. Multicentre audit of inpatient management of acute exacerbations of chronic obstructive pulmonary disease: comparison with clinical guidelines. Intern Med J. 2012;42(4):380-387. doi:10.1111/j.1445-5994.2011.02475.x

53. Seys D, Bruyneel L, Sermeus W, et al. Teamwork and adherence to recommendations explain the effect of a care pathway on reduced 30day readmission for patients with a COPD exacerbation. COPD. 2018;15(2):157-164. doi:10.1080/15412555.2018.1434137

54. Pozo-Rodríguez F, López-Campos JL, Álvarez-martínez CJ, et al. Clinical audit of COPD patients requiring hospital admissions in Spain: AUDIPOC study. PLoS One. 2012;7(7):e42156. doi:10.1371/ journal.pone. 0042156

55. Jouleh B, Erdal M, Eagan TM, et al. Guideline adherence in hospital recruited and population based COPD patients. BMC Pulm Med. 2018;18(1):1-9. doi:10.1186/s12890-018-0756-8

56. Desalu OO, Onyedum CC, Adeoti AO, et al. Unmet needs in asthma treatment in a resource-limited setting: findings from the survey of adult asthma patients and their physicians in Nigeria. Pan Afr Med J. 2013;16:1-13. doi:10.11604/pamj.2013.16.20.2798

57. Sen B, Woollard M, Desira NL. Does the introduction of a COPD pro-forma improve the standards of care delivered by junior doctors in the emergency department. COPD. 2010;7(3):199-203. doi: $10.3109 / 15412555.2010 .481699$ 
58. Masoompour SM, Mohammadi A, Mahdaviazad H. Adherence to the Global Initiative for Chronic Obstructive Lung Disease guidelines for management of COPD: a hospital-base study. Clin Respir J. 2016;10 (3):298-302. doi:10.1111/crj.12215

59. Pumar IM, Gray CR, Walsh RJ, Yang. IA, Rolls TA, Ward DL. Anxiety and depression-Important psychological comorbidities of COPD. J Thorac Dis. 2014;11(6):1615-1631.

60. Smallwood N, Currow D, Booth S, et al. Attitudes to specialist palliative care and advance care planning in people with COPD: a multi-national survey of palliative and respiratory medicine specialists. BMC Palliat Care. 2018;17(1):1-8. doi:10.1186/s12904-0180371-8

61. Crawford G, Brooksbank MA, Brown M, et al. Unmet needs of people with end-stage chronic obstructive pulmonary disease: recommendations for change in A ustralia. Intern Med J. 2013;43(2):183190. doi:10.1111/j.1445-5994.2012.02791.x

62. Smallwood N, Thompson M, Warrender-Sparkes M, et al. Integrated respiratory and palliative care may improve outcomes in advanced lung disease. ERJ Open Res. 2018;4(1):00102-2017. doi:10.1183/ 23120541.00102-2017

63. Vermylen JH, Szmuilowicz E, Kalhan R. Palliative care in COPD: an unmet area for quality improvement. Int J Chron Obstruct Pulmon Dis. 2015;10:1543. doi:10.2147/COPD.S74641
64. Bloom CI, Slaich B, Morales DR, et al. Low uptake of palliative care for COPD patients within primary care in the UK. Eur Respir J. 2018;51(2):1701879. doi:10.1183/13993003.01879-2017

65. Philip J, Crawford G, Brand C, et al. A conceptual model: redesigning how we provide palliative care for patients with chronic obstructive pulmonary disease. Palliat Support Care. 2018;16(4):452-460. doi:10.1017/S147895151700044X

66. Seys D, Bruyneel L, Decramer M, et al. An international study of adherence to guidelines for patients hospitalised with a COPD exacerbation. COPD. 2017;14(2):156-163. doi:10.1080/ 15412555.2016 .1257599

67. Considine J, Botti M, Thomas S. Emergency department management of exacerbation of chronic obstructive pulmonary disease: audit of compliance with evidence-based guidelines. Intern Med J. 2011;41 (1a):48-54. doi:10.1111/j.1445-5994.2009.02065.x

68. Moher D, Liberati A, Altman D, et al. The PRISMA statement for reporting systematic reviews and meta-analyses of studies that evaluate health care interventions: explanation and elaboration. J Clin Epidemiol. 2009;62(10). doi:10.1016/j.jclinepi.2009.06.005
Journal of Multidisciplinary Healthcare

\section{Publish your work in this journal}

The Journal of Multidisciplinary Healthcare is an international, peerreviewed open-access journal that aims to represent and publish research in healthcare areas delivered by practitioners of different disciplines. This includes studies and reviews conducted by multidisciplinary teams as well as research which evaluates the results or conduct of such teams or healthcare processes in general. The journal

\section{Dovepress}

covers a very wide range of areas and welcomes submissions from practitioners at all levels, from all over the world. The manuscript management system is completely online and includes a very quick and fair peer-review system. Visit http://www.dovepress.com/testimonials. php to read real quotes from published authors. 